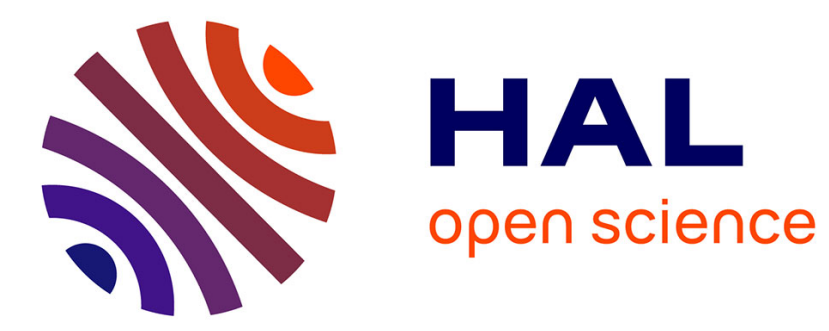

\title{
On the path to gold: Monoanionic Au bisdithiolate complexes with antimicrobial and antitumor activities
}

Sílvia A Sousa, Jorge H Leitão, Rafaela a L Silva, Dulce Belo, Isabel C

Santos, Joana F Guerreiro, Marta Martins, Diana Fontinha, Miguel

Prudêncio, Manuel Almeida, et al.

\section{To cite this version:}

Sílvia A Sousa, Jorge H Leitão, Rafaela a L Silva, Dulce Belo, Isabel C Santos, et al.. On the path to gold: Monoanionic Au bisdithiolate complexes with antimicrobial and antitumor activities. Journal of Inorganic Biochemistry, 2020, 202, pp.110904. 10.1016/j.jinorgbio.2019.110904 . hal-02364867

\section{HAL Id: hal-02364867 \\ https://hal-univ-rennes1.archives-ouvertes.fr/hal-02364867}

Submitted on 11 Dec 2019

HAL is a multi-disciplinary open access archive for the deposit and dissemination of scientific research documents, whether they are published or not. The documents may come from teaching and research institutions in France or abroad, or from public or private research centers.
L'archive ouverte pluridisciplinaire HAL, est destinée au dépôt et à la diffusion de documents scientifiques de niveau recherche, publiés ou non, émanant des établissements d'enseignement et de recherche français ou étrangers, des laboratoires publics ou privés. 


\section{On the Path to Gold: Monoanionic Au Bisdithiolate Complexes with Antimicrobial and} Antitumor Activities

Sílvia A. Sousa ${ }^{1}$, Jorge H. Leitão ${ }^{1}$, Rafaela A.L. Silva ${ }^{2}$, Dulce Belo ${ }^{2}$, Isabel C. Santos ${ }^{2}$, Joana F. Guerreiro ${ }^{2}$, Marta Martins ${ }^{3}$, Diana Fontinha ${ }^{3}$, Miguel Prudêncio ${ }^{3}$, Manuel Almeida $^{2}$, Dominique Lorcy ${ }^{4}$, Fernanda Marques ${ }^{2} *$

${ }^{1}$ iBB-Institute for Bioengineering and Biosciences, Departamento de Bioengenharia, Instituto Superior Técnico, Universidade de Lisboa, Av. Rovisco Pais, 1049-001 Lisboa, Portugal.

${ }^{2}$ Centro de Ciências e Tecnologias Nucleares, Instituto Superior Técnico, Universidade de Lisboa, Estrada Nacional 10, km 139.7, 2695-066 Bobadela LRS, Portugal.

${ }^{3}$ Instituto de Medicina Molecular- João Lobo Antunes, Faculdade de Medicina, Universidade de Lisboa, Avenida Professor Egas Moniz, 1649-028 Lisboa, Portugal.

${ }^{4}$ Institut des Sciences Chimiques de Rennes UMR 6226, Université de Rennes 1, Campus de Beaulieu, 35042 Rennes, France.

* Corresponding authors:

sousasilvia@tecnico.ulisboa.pt

fmarujo@ctn.tecnico.ulisboa.pt

*These authors contributed equally to this work

\section{Abstract}

The emergence of resistance to antimicrobial and anticancer drugs poses severe threats to public health worldwide, highlighting the need for more efficient treatments. Here, four monoanionic $\mathrm{Au}$ bisdithiolate complexes $\left[\mathrm{Au}(\mathrm{mnt})_{2}\right]^{-}$(where $\mathrm{mnt}=1,1$ dicyanoethylene-2,2-dithiolate)(1), $\left[\mathrm{Au}(i \text {-mnt })_{2}\right]^{-}$(where $i$-mnt $=$ 2,2-dicyanoethylene1,1-dithiolate)(2), $\left[\mathrm{Au}(\mathrm{cdc})_{2}\right]^{-}$(where $\mathrm{cdc}=$ cyanodithioimido carbonate $)(\mathbf{3})$, and $\left[\mathrm{Au}(\mathrm{qdt})_{2}\right]^{-} \quad($ where $\mathrm{qdt}=$ quinoxaline-2,3-dithiolate $)(4)$ were screened for their antimicrobial and antitumor activities. Complexes $\mathbf{3}$ and $\mathbf{4}$ showed antibacterial activity against Staphylococcus aureus $(\mathrm{MIC}=15.3$ and $14.7 \mu \mathrm{g} / \mathrm{mL}$, respectively). Complex 3 
also caused significant growth inhibition of Candida glabrata $(\mathrm{MIC}=7.0 \mu \mathrm{g} / \mathrm{mL}$ ). Concentrations of complexes 1-4 up to $125 \mu \mathrm{g} / \mathrm{mL}$ had no growth inhibition activity against Escherichia coli. The cytotoxic activity of complexes 1-4 was evaluated against the ovarian cancer cells A2780 and A2780cisR, sensitive and resistant to cisplatin, respectively. All compounds showed high cytotoxic activities against both tumoral cell lines, exhibiting $\mathrm{IC}_{50}$ values in the low micromolar range $(0.9-5.5 \mu \mathrm{M})$ upon $48 \mathrm{~h}$ incubation. In contrast to complex $\mathbf{1}$, the complexes 2-4 induced a dose-dependent formation of reactive oxygen species (ROS), similar to the observed for the reference drugs auranofin and cisplatin. Opposite to $\mathbf{4}$, complexes 1-3 were able to activate caspase $3 / 7$, suggesting the involvement of apoptosis in the mechanism of cell death. Contrasting with cisplatin, complexes $3, \mathbf{4}$ and auranofin did not cause DNA damage. Combined, these data provide evidence that these monoanionic gold bisdithiolates, particularly complex $\mathbf{3}$, are potential lead compounds to further explore as therapeutic drugs.

\section{Keywords}

Monoanionic Au complexes; Dithiolates; Antimicrobial; Antitumor; Reactive oxygen species (ROS); DNA interaction. 


\section{Introduction}

The burden of human infectious diseases remains a serious threat to public health worldwide. In addition, the emergence of resistance to the clinically in-use antimicrobials among bacteria, fungi and parasites, lowers the efficacy of available prevention and treatment measures [1]. The World Health Organization (WHO) released a list of bacteria for which new antibiotics are urgently needed. The top priority species were summarized under the acronym ESKAPE, comprising the Gram-positive Enterococcus faecium and Staphylococcus aureus, and the Gram-negative Klebsiella pneumoniae, Acinetobacter baumannii, Pseudomonas aeruginosa, and Enterobacter spp. [2]. Fungal human infections are also associated with high morbidity and mortality rates, especially among immunocompromised patients, such as HIV-infected patients and cancer patients [3].

Another global health concern is the rise in the incidence of cancer, which remains one of the most common causes of death worldwide [4]. With advances in cancer treatment, in particular with the use of chemotherapeutic drugs, the prognosis and survival rate of patients have improved considerably over the past decades for several types of cancers. However, the toxicity and severe side effects associated with the majority of the anticancer drugs currently available has led to an increase in opportunistic infections [5]. Moreover, chronic infections with pathogenic microorganisms lead to inflammation and decreased immunological defences, contributing to the proliferation of cancer cells [6-8]. Therefore, new classes of compounds with both antimicrobial and antitumor properties that act on non-classical targets have been recently developed and studied [9]. One of those molecules, auranofin, a coordinated gold(I) complex commonly used for the treatment of rheumatoid arthritis, was proposed for drug repositioning as a new antimicrobial and antitumor agent. Auranofin has progressed to FDA approved clinical 
trials in various types of tumors such as leukemia and ovarian cancer, even though the molecular mechanisms underlying the antitumor activity in ovarian cancer cells are not yet fully understood [10,11]. In addition, auranofin is also used as a reference compound when novel gold-based compounds are evaluated as prospective therapeutic drugs [11].

The cytotoxicity of gold complexes usually involves the inhibition of enzymes, especially those containing thiol groups. Therefore, the strong binding affinity of gold to thiol groups makes thioredoxin reductases (TrxR), glutathione reductases (GR) and cysteine proteases, all overexpressed in cancer cells, potential targets for gold complexes [12]. Inhibition of these enzymes activity can impair the redox state of the cell and lead to increased production of reactive oxygen species (ROS), causing cellular oxidative stress and leading to intrinsic apoptosis. This mechanism of action is distinct from the mechanism of action of platinum-based metallodrugs currently used in anticancer therapies, such as cisplatin, which mainly rely on direct interaction with the DNA [13]. Due to the emergence of drug resistance of cancer cells to these metallodrugs and the undesirable toxic effects that constitute a current barrier to a successful treatment, novel antitumor drugs are currently being pursued [14].

Transition metal bisdithiolates have been extensively studied as building blocks of new molecular conductors and magnets [15]. Their usual square planar molecular structure, stability, and vivid redox behaviour, make them also suitable candidates to be explored on different areas of research, namely their biological applications. Studies on the biological properties of dithiolate complexes have been limited to a few examples, such as cobalt(II), copper(II), nickel(II) and zinc(II) furanylmethyl- and thienylmethyl dithiolenes, which possess significant antibacterial and antifungal activity [16]. More recently, gold(III) 1,2-dithiolene cyclometalated complexes were also found to exhibit 
antimicrobial and cytotoxic activities [17]. However, the molecular structure of the reported complexes differs significantly from the square planar homoleptic transition metal bisdithiolates studied in this work. We selected four homoleptic monoanionic gold bisdithiolate complexes [18-22] (Figure 1) to be explored for their antimicrobial and antitumor activities, and to gain clues into their structure-activity relationship. These complexes were previously used to prepare molecular materials as salts with several organic donors [18-22], but the structure of $\mathbf{3}$ and $\mathbf{4}$ as salts with simple cations was never reported. To our knowledge, the work reported herein constitutes the first systematic study aiming to explore the biological properties of this type of compounds.

\section{Materials and Methods}

\subsection{Compounds}

The gold complexes TBA[Au(mnt $\left.)_{2}\right](\mathbf{1}), \operatorname{TBA}\left[\mathrm{Au}(i-\mathrm{mnt})_{2}\right](\mathbf{2}), \mathrm{TBA}\left[\mathrm{Au}(\mathrm{cdc})_{2}\right](\mathbf{3})$, and $\mathrm{TPP}\left[\mathrm{Au}(\mathrm{qdt})_{2}\right]$ (4) were prepared as tetrabutyl ammonium (TBA) and tetraphenylphosphonium (TPP) salts by previously described methods [23-29]. Auranofin and cisplatin were purchased from Sigma-Aldrich.

\subsection{Cells and cell culture media}

A2780 (cisplatin sensitive) and A2780cisR (cisplatin resistant) ovarian tumour cells were purchased from Sigma-Aldrich. V79 (hamster lung fibroblasts) were purchased from ATCC (American Type Culture Collection). RPMI and DMEM/F12 cell media and medium supplements were purchased from Gibco (Thermo Fisher Scientific).

\subsection{Bacterial and fungal strains and culture media}


The bacterial strains Staphylococcus aureus Newman and Escherichia coli ATCC25922, and the fungal strains Candida glabrata CBS138 and Candida albicans SC5134 were used. The bacterial and fungal strains were isolated from human infections [30-33]. When in use, bacterial strains were maintained in Lennox Broth (LB) solid medium (10 g/L tryptone, $5 \mathrm{~g} / \mathrm{L}$ yeast extract, $5 \mathrm{~g} / \mathrm{L} \mathrm{NaCl}$ and $15 \mathrm{~g} / \mathrm{L}$ agar), while fungal strains were maintained in Yeast Extract-Peptone-Dextrose (YPD) solid medium (20 g/L glucose, $20 \mathrm{~g} / \mathrm{L}$ peptone, $10 \mathrm{~g} / \mathrm{L}$ yeast extract and $15 \mathrm{~g} / \mathrm{L}$ agar), as previously described [34].

\subsection{Cyclic voltammetry}

Cyclic voltammetry data were obtained using a BAS C3 Cell Stand. The voltammograms were obtained at room temperature with variable scan rates in the range of 20-500 mV.s ${ }^{-1}$, a platinum working wire and counter electrodes and a $\mathrm{Ag} / \mathrm{AgNO}_{3}$ (0.01 $\mathrm{M} \mathrm{AgNO}_{3}$ and $0.1 \mathrm{M} \mathrm{TBAPF}_{6}$ in acetonitrile) reference electrode, in which the $\mathrm{Ag}^{+}$ion electrode was separated from the bulk solution by a VycorTM frit. The measurements were performed on fresh solutions with a concentration of $1 \times 10^{-3} \mathrm{M}$, in acetonitrile, that contained $\mathrm{TBAPF}_{6}\left(1 \times 10^{-1} \mathrm{M}\right)$ as a supporting electrolyte. Ferrocene was added directly to the solution after analysis of the analyte of interest to allow the potentials normalization in situ, relatively to the ferrocene/ferrocenium couple redox potential.

\section{$2.5 X$-ray crystallography}

Suitable crystals for X-ray diffraction were mounted on a loop with protective oil, and X-ray data was collected on a Bruker APEX II CCD detector diffractometer using graphite monochromated MoK $\alpha$ radiation $(\lambda=0.71073 \AA)$ and operated in a $\varphi$ and $\omega$ 
scans mode. A semi empirical absorption correction was carried out using SADABS (Sheldrick, G. M. SADABS, Bruker AXS Inc., Madison, Wisconsin, USA, 2004). Data collection, cell refinement and data reduction were done with the SMART and SAINT programs (SMART and SAINT, Bruker AXS Inc., Madison, Wisconsin, USA, 2004). The structures were solved by direct methods using SIR97 [35] and refined by fullmatrix least-squares methods using the program SHELXL97 [36] using the winGX software package [37]. Non-hydrogen atoms were refined with anisotropic thermal parameters, except in cases of disorder where these specific atoms were refined as isotropic, whereas H-atoms were placed in idealized positions and allowed to refine riding on the parent $\mathrm{C}$ atom. Molecular graphics were prepared using ORTEP [38].

\subsection{Intermolecular energy interactions calculations}

The interaction energies were calculated with the freeware PrimeColor Software, CAESER [39]. The program employs the extended Hückel method [40-42], where the basis set consists of Slater type orbitals of double- $\zeta$ quality. The exponents, contraction coefficients and atomic parameters were taken from previous work [43].

\subsection{Determination of antibacterial activity}

The antibacterial activity of the complexes 1-4 was assessed according to standard methods (NCCLS), and as previously described [44-46], using 96-well polystyrene microtiter plates (Greiner Bio-One). Stock solutions of the tested complexes were prepared in 100\% DMSO at final concentrations of $10 \mathrm{mg} / \mathrm{mL}$ (complexes 1 and 2), or 5

$\mathrm{mg} / \mathrm{mL}$ (complexes 3 and $\mathbf{4}$, and auranofin), depending on the solubility of each complex. Briefly, to each well, $100 \mu$ aliquots of serial 1:2 dilutions of stock solutions prepared for each complex in Mueller-Hinton (MH) broth (Fluka Analytical) were 
added, in order to obtain final concentrations ranging from $125 \mu \mathrm{g} / \mathrm{mL}$ to $0.49 \mu \mathrm{g} / \mathrm{mL}$. Then, $100 \mu \mathrm{l}$ of adequately diluted bacterial suspensions (S. aureus Newman or E. coli ATCC 25922) were added and mixed with the serially diluted complexes, in order to obtain a final optical density of 0.01 , measured at $640 \mathrm{~nm}\left(\mathrm{OD}_{640}\right)$, in a Hitachi U-2000 UV/Vis spectrophotometer. These bacterial suspensions were obtained from $5 \mathrm{~h}$ grown bacterial cultures (carried out in $\mathrm{MH}$ broth at $37^{\circ} \mathrm{C}$ and 250 rev. $\mathrm{min}^{-1}$ ), and adequately diluted with fresh MH medium. When testing auranofin towards S. aureus Newman, additional concentrations ranging from $0.49 \mu \mathrm{g} / \mathrm{mL}$ to $0.06 \mu \mathrm{g} / \mathrm{mL}$ were also used. After $24 \mathrm{~h}$ of incubation at $37{ }^{\circ} \mathrm{C}$, the wells were examined for turbidity (growth), resuspended by pipetting, and their optical density was measured in a SPECTROstar Nano microplate reader (BMG Labtech) at $640 \mathrm{~nm}$.

All complexes were tested in three independent experiments and in duplicate wells. Minimum inhibitory concentration (MIC) values were estimated after data fitting of the $\mathrm{OD}_{640}$ mean values using a modified Gompertz equation as described by Lambert and Pearson, using the GraphPad Prism software (version 6.07) [47]. In each experiment, positive (without complex) and negative controls (no organism inoculum) were performed. The effect of $5 \%(\mathrm{~V} / \mathrm{V})$ DMSO on bacterial growth was also determined.

\subsection{Determination of antifungal activity}

Antifungal susceptibility testing was carried out according to the standardized microdilution method recommended by EUCAST (European Committee on Antimicrobial Susceptibility Testing) for Candida spp. [48], and as previously described [34,49]. Briefly, 96-well microtiter plates (Greiner Bio-One) were filled with $100 \mu \mathrm{l}$ aliquots of 1:2 serially diluted stock solutions of each complex, prepared as described in 2.7 , in order to obtain final concentrations ranging from $125 \mu \mathrm{g} / \mathrm{mL}$ to 0.49 
$\mu \mathrm{g} / \mathrm{mL}$. Stock solutions were prepared in RPMI $2 \%$ G. RPMI $2 \% \mathrm{G}$ is composed of RPMI-1640 liquid medium (SIGMA) supplemented with $20 \mathrm{~g} / \mathrm{L}$ glucose (final concentration), buffered to $\mathrm{pH} 7.0$ with $0.165 \mathrm{M}$ morpholinepropanesulphonic acid (MOPS; SIGMA). To these aliquots, $100 \mu \mathrm{L}$ of diluted fungal suspensions (C. glabrata CBS138 or C. albicans SC5134) were added. Diluted fungal suspensions were prepared from overnight grown cultures (carried out in YPD broth at $30{ }^{\circ} \mathrm{C}$ and 250 rev. $\mathrm{min}^{-1}$ ), diluted with RPMI-1640 fresh liquid medium to a final optical density of 0.025 , measured at $530 \mathrm{~nm}\left(\mathrm{OD}_{530}\right)$ in a Hitachi U-2000 UV/Vis spectrophotometer. After $24 \mathrm{~h}$ of incubation at $35^{\circ} \mathrm{C}$, the wells were examined for turbidity (growth), resuspended and their optical density was measured in a SPECTROstar Nano microplate reader (BMG Labtech) at $530 \mathrm{~nm}$.

All compounds were tested at least in three independent experiments and in duplicate wells. Minimum inhibitory concentration (MIC) was estimated after data fitting of the $\mathrm{OD}_{530}$ mean values using a modified Gompertz equation, using the GraphPad Prism software (version 6.07) [47]. In each experiment, positive (without compound) and negative controls (no organism inoculum) were carried out. The effect of $1.25 \%$ (V/V) DMSO on fungal growth was also evaluated.

\subsection{Determination of cytotoxic activity}

The cytotoxic activity of the tested compounds was evaluated in ovarian cancer cells A2780 (cisplatin sensitive) and A2780cisR (cisplatin resistant), and in normal fibroblasts V79. All cell lines were grown in RPMI medium supplemented with $10 \%$ FBS and maintained in a humidified incubator (Heraeus, Germany) with $5 \% \mathrm{CO}_{2} / 95 \%$ air. Cell viability was measured by the colorimetric MTT assay. The assay measures the conversion of 3-(4,5-dimethythiazol2-yl)-2,5-diphenyl tetrazolium bromide (MTT) to 
an insoluble formazan product by mitochondrial dehydrogenase enzymes active in live cells. For the assay, cells were seeded in 96-well plates at a density of $2 \times 10^{4}$ cells in $200 \mu \mathrm{L}$ medium and allowed to attach for $24 \mathrm{~h}$. Complexes 1-4 were first diluted in DMSO for complete solubility and then in medium to prepare serial dilutions in the range $10^{-7}-10^{-4} \mathrm{M}$. The concentration of DMSO in the medium did not exceed $1 \%$ and had no cytotoxic effect. The reference compounds cisplatin and auranofin were first diluted in water (cisplatin) and DMSO (auranofin) and then in medium in the same concentration range of the complexes. After careful removal of the medium, $200 \mu \mathrm{L}$ of each compound's dilution in fresh medium were added to the cells and incubated for 3 , 24 and $48 \mathrm{~h}$ at $37^{\circ} \mathrm{C}$. At the end of the treatment, the medium was discarded and $200 \mu \mathrm{L}$ of MTT solution in PBS $(0.5 \mathrm{mg} / \mathrm{mL})$ were applied to each well. After $3 \mathrm{~h}$ at $37{ }^{\circ} \mathrm{C}$, the medium was removed and replaced by DMSO $(200 \mu \mathrm{L})$ to solubilize the formazan crystals formed. The percentage of cellular viability was assessed measuring the absorbance at $570 \mathrm{~nm}$ using a plate spectrophotometer (Power Wave Xs, Bio-Tek). The $\mathrm{IC}_{50}$ values were calculated using the GraphPad Prism software (version 5.0). Results are shown as the mean $\pm \mathrm{SD}$ of at least two independent experiments done with six replicates each.

\subsection{Measurement of reactive oxygen species (ROS)}

\subsubsection{NBT assay}

Superoxide anion was detected with nitroblue tetrazolium (NBT) (NBT= 2.2'-bis(4Nitrophenyl)-5,5'-diphenyl-3,3'-(3,3'-dimethoxy-4,4'-diphenylene)ditetrazolium chloride), a yellow water-soluble tetrazolium compound. NBT reacts with cellular superoxide anions to form a dark blue formazan derivative that can be detected by its absorbance at $550 \mathrm{~nm}$. The experimental procedure followed an adaptation of 
previously described methods [50,51]. For the assay, A2780 cells $\left(2 \times 10^{4} /\right.$ well $)$ in RPMI were seeded in 96-well plates and left to adhere overnight. Then, cells were incubated with 10,20 or $50 \mu \mathrm{M}$ of the compounds for $1 \mathrm{~h}$ at $37^{\circ} \mathrm{C}$, followed by addition of $20 \mu \mathrm{L}$ of a NBT solution $(10 \mathrm{mg} / \mathrm{mL}$ PBS $)$. The incubation was allowed to proceed for an additional $1 \mathrm{~h}$ at $37{ }^{\circ} \mathrm{C}$. The medium was then gently discarded and the formazan deposits were solubilized with $200 \mu \mathrm{L}$ of $90 \%$ DMSO:10\% $0.01 \mathrm{M} \mathrm{NaOH}$ and $0.1 \%$ SDS. The absorbance of each well was measured at $550 \mathrm{~nm}$. Each experiment was repeated twice and each concentration tested with at least six replicates per experiment. Results (mean $\pm \mathrm{SD}$ ) are expressed as $\%$ of controls (no treatment).

\subsection{2 $\mathrm{H}_{2}$ DCFDA assay}

The production of intracellular ROS, namely hydrogen peroxide, hydroxyl radicals and peroxynitrite, was detected by fluorescence using the cell permeant fluorogenic dye $\mathrm{H}_{2}$ DCFDA (dihydro-2'7'dichlorofluorescein diacetate) on a microplate-based assay [52]. $\mathrm{H}_{2}$ DCFDA is deacetylated by intracellular esterases to a non-fluorescent compound, which is later converted into the highly fluorescent $2^{\prime}, 7^{\prime}$-dichlorofluorescein (DCF) upon oxidation by ROS. DCF fluorescence was detected using maximum excitation and emission spectra of 492 and $517 \mathrm{~nm}$, respectively.

For the $\mathrm{H}_{2}$ DCFDA assays, A2780 cells $\left(2 \times 10^{4} /\right.$ well) were seeded in 96-well plates and left to attach overnight. Then, the medium on each well was replaced with a solution of $10 \mu \mathrm{M} \mathrm{H}_{2}$ DCFDA in phenol red-free DMEM/F12 and cells were further incubated at 37 ${ }^{\circ} \mathrm{C}$ for $30 \mathrm{~min}$. This solution was then removed and cells were incubated with fresh phenol red-free DMEM/F12 medium containing 10,20 or $50 \mu \mathrm{M}$ of each test complex, hydrogen peroxide (positive control) or the reference drugs auranofin and cisplatin at the same concentrations $(10,20$ and $50 \mu \mathrm{M})$ for $3 \mathrm{~h}$. For the combined assays with the 
ROS scavengers, the complexes at $50 \mu \mathrm{M}$ were co-incubated with sodium pyruvate (10 $\mathrm{mM})$, sodium bicarbonate $(10 \mathrm{mM})$ and DMSO $(0.5 \%)$ for $3 \mathrm{~h}$. Results are shown as the mean \pm SD of a representative experiment done with four replicates per condition.

\subsection{Apoptosis (caspase 3/7 assay)}

Apoptosis (caspase 3/7 assay) was assessed using a Caspase-Glo®3/7 Assay (Promega). The assay provides a proluminescent caspase- $3 / 7$ substrate that is cleaved in the presence of caspase $3 / 7$ to release aminoluciferin, the luciferase substrate used in the production of light. The luminescent signal is proportional to the caspase activity present in the cells. The assay employed A2780 cells, in phenol red-free DMEM/F12 medium, in 96 wells plates, treated with the compounds for $24 \mathrm{~h}$, at concentrations equivalent to their $\mathrm{IC}_{50}$ values. Zinc acetate $(50 \mu \mathrm{M})$ was co-incubated with the complexes. After $24 \mathrm{~h}$ of incubation, $100 \mu \mathrm{L}$ of medium were removed from each well. Caspase $3 / 7 ®$ reagent was added at a 1:1 ratio and the plate was shaken in an orbital shaker for $30 \mathrm{~s}$ at $300-500 \mathrm{rpm}$. The plate was incubated at room temperature for 90 min, protected from light. Luminescence intensity was measured using an Infinite 200

Plate Reader (Tecan). Each experiment was performed in duplicate and each concentration was tested with at least three replicates. Results (mean $\pm \mathrm{SD}$ ) were expressed as relative fluorescence units.

\subsection{DNA interaction}

DNA interaction was assessed by monitoring the electrophoretic mobility of the supercoiled $\phi X 174$ DNA, as previously described [53]. Briefly, each reaction mixture contained, in a final volume of $20 \mu \mathrm{L}, 200 \mathrm{ng}$ of supercoiled $\phi X 174$ DNA (Promega) in $10 \mathrm{mM}$ phosphate buffer ( $\mathrm{pH}$ 7.2) with different concentrations of cisplatin, auranofin, 
or the metal complexes. After incubation in the dark for $24 \mathrm{~h}$ at $37^{\circ} \mathrm{C}, 2 \mu \mathrm{l}$ of $10 \times$ DNA loading buffer (Applichem) was added to each tube and the samples were loaded on an $0.8 \%$ agarose gel in TBE buffer (Thermo Fisher Scientific). The electrophoresis was carried out for about $3 \mathrm{~h}$ at $90 \mathrm{~V}$. Samples with non-incubated plasmid and plasmid incubated with DMSO were used as controls. The gels were then stained in a $3 x$ GelRed ${ }^{\circledR}$ (Biotium) staining solution in $\mathrm{H}_{2} \mathrm{O}$, according to the manufacturer's instructions. Bands were visualized using an AlphaImagerEP (Alpha Innotech) under UV light.

\section{Results and Discussion}

\subsection{Crystal Structures}

The structure of complexes $\mathbf{1}$ and $\mathbf{2}$ were previously reported. In this work we describe the structure of complexes $\mathbf{3}$ and $\mathbf{4}$ as tetrabutylammonium and tetraphenylphosphonium salts.

\subsubsection{Complex 3}

$\mathrm{TBA}\left[\mathrm{Au}(\mathrm{cdc})_{2}\right](3)$ crystallizes in the monoclinic system, space group $P 2_{1} / c$ (Table $\mathrm{S} 1$ ). The unit cell contains an anion and a cation, both molecules at general positions. The anionic molecule presents the usual square coordination geometry and, within the experimental error, it is planar (Figure 2, Table S2).

The crystal structure consists of stair-like chains of anion pairs, running parallel to the $a$ axis (Figure 3). The angle between the molecules' average plane in neighbouring chains is $76^{\circ}$. There are no interactions between molecules in different chains. Along the chains, the pairs of anions are connected by side-by-side $\mathrm{S} \cdots \mathrm{S}$ and $\mathrm{S} \cdots \mathrm{N}$ short contacts (Figure 4, Table S3). Between pairs, the overlapping mode between anions places the sulphur atoms on top of the gold atom, inducing a soft molecular slipping both along the 
longest and minor molecular axis. The cations fill the spaces between anionic chains.

Several C-H $\cdots \mathrm{S}$ and $\mathrm{C}-\mathrm{H} \cdots \mathrm{N}$ hydrogen bonds connect the anions and the cations.

\subsubsection{Complex 4}

TPP $\left[\mathrm{Au}(\mathrm{qdt})_{2}\right]$ (4) crystallizes in the monoclinic system, space group P2/n (Table S1). The unit cell contains two anions and two cations at an inversion center. The anionic molecules present a square coordination geometry of the $\mathrm{Au}-\mathrm{S}_{4}$ core, with the quinoxaline skeleton of the two ligands pointing up in opposite directions, conferring a chair type distortion to the molecule (Figure $2 b-c$, Table S4). The crystal structure is composed of a 3D anionic network where each anion is surrounded by other four anions placed almost perpendicularly $\left(86^{\circ}\right)$ to its molecular average plan (Figure 5). The anions in this gridding arrangement are connected by $\mathrm{C}-\mathrm{H} \cdots \mathrm{S}$ hydrogen bonds, involving the coordinating sulphur atoms and the more external hydrogen atom of the phenyl ring (Table S5). The cations are placed in tunnels shaped by the anionic grid along $b$, and interact with the anions throughout $\mathrm{C}-\mathrm{H} \cdots \mathrm{S}$ and $\mathrm{C}-\mathrm{H} \cdots \mathrm{N}$ hydrogen bonds and $\pi-\pi$ interactions comprising the cation phenyl ring and the extended aromatic ring of the anion ligands.

The homoleptic monoanionic gold bisdithiolate complexes are essentially planar molecules with a square planar coordination geometry. This is also the case for the gold complexes 1-4. Deviations of planarity are usually associated to intermolecular interactions with neighbouring molecules, throughout the ligands, yielding soft chair or boat type molecular configurations or, due to the flexibility of the Au-S bond, inducing different degrees of tetrahedral distortions of the $\mathrm{AuS}_{4}$ core. Figure 6 represents different intermolecular interactions in complexes 1-4. 
In the crystal structures of complexes $\mathbf{1 - 4}$, the major difference between anions is the size of the electronic cloud (Figure 7). Although the anions in $\mathbf{1}$ and $\mathbf{2}$ are isostructural, the $i$-mnt ligand is slightly larger than the related $m n t$. Both the ligands in $\mathbf{3}$ and $\mathbf{1}$ present a similar electronic cloud; however, in $\mathbf{3}$ the asymmetric trans configuration potentiates intermolecular interactions less constrained by stereochemical effects. Although bearing the same four nitrogen atoms as the previous complexes, the ligand in 4 has a quinoxaline moiety, a more extended aromatic system that besides enlarging the molecular size also enables $\pi-\pi$ interactions.

One of the most important aspects of transition metal bisdithiolenes is their vivid redox behaviour, making readily accessible several oxidation states, from monoanionic, to dianionic, neutral and even cationic states [54]. In the case of gold bisdithiolates, the monoanionic state is the most common and stable. The organic dithiolene ligands play a non-innocent role in the modulation of the redox properties of these complexes by contributing, in different degrees, to the molecular orbitals. This is illustrated in Figure 8, representing the HOMO of the anions in complexes 1-4. These results denote that the oxidation processes are more ligand centered in the case of $c d c$ (3) and $q d t$ (4) complexes than in the case of mnt (1) and $i$-mnt (2).

\subsection{Cyclic Voltammetry}

The redox properties of complexes $\mathbf{1 - 4}$, in $\mathrm{CH}_{3} \mathrm{CN}$ solutions, were studied by cyclic voltammetry, at room temperature, using $\mathrm{Ag} / \mathrm{AgNO}_{3}$ as the reference electrode. The redox potential of the ferrocene/ferrocenium couple was used as an internal reference. The results are summarized in Figure 9, Table 1 and Figure S1.

Complex 1 undergoes a quasi-reversible one electron oxidation process, centered at 793 $\mathrm{mV}$, ascribed to the couple $\left[\mathrm{Au}(\mathrm{mnt})_{2}\right]^{-1} /\left[\mathrm{Au}(\mathrm{mnt})_{2}\right]^{-2}$. In the case of compound 2 , an 
irreversible redox process at $-829 \mathrm{mV}$ is observed, attributed to the reduction of the monoanionic to the dianionic species $\left(\left[\mathrm{Au}(i-\mathrm{mnt})_{2}\right]^{-1} \rightarrow\left[\mathrm{Au}(i-\mathrm{mnt})_{2}\right]^{-2}\right)[55]$. In the range $-1 / 1 \mathrm{~V}$, no redox processes were visible for complex $\mathbf{3}$, suggesting a higher stability of this $\left[\mathrm{Au}(\mathrm{cdc})_{2}\right]^{-}$monoanion. Complex $\mathbf{4}$ presents a slightly different voltammogram, showing two distant peaks, one cationic and one anionic, at -701 and +901 mV, respectively. The peak at more positive potentials was revealed to be interdependent of the process occurring at more negative potentials.

The irreversible reduction process observed in the case of $\mathbf{4}$ is likely to reflect the transition from the monoanionic to the dianionic species $\left(\left[\mathrm{Au}(\mathrm{qdt})_{2}\right]^{-1} \rightarrow\left[\mathrm{Au}(\mathrm{qdt})_{2}\right]^{-2}\right)$.

With the exception of complex $\mathbf{3}$, where no processes were observed in the range of the potentials studied, the ligand does not substantially affect the redox potentials concerning the couple $\left([\mathrm{AuL}]^{-1} /[\mathrm{AuL}]^{-2}\right)$, although only in the case of $\left[\mathrm{Au}(\mathrm{mnt})_{2}\right]^{-}$it is a quasi-reversible process.

\subsection{Studies on complexes stability in solution by $U V$-vis spectroscopy}

In order to evaluate the stability of complexes 1-4 in solution, a series of UV-Vis spectra were collected during $48 \mathrm{~h}$. The spectra of DMSO solutions of complexes 1-4, were recorded in phenol red-free DMEM/F12 medium, in the absence or presence of fetal bovine serum (FBS). As a reference, the spectra of complexes 1-4 in DMSO were also collected. Results from this study support the cyclic voltammetry data, suggesting that complex 3 (Figure 10) is the most stable complex of this series of gold bisdithiolates. Distinctly from the other complexes (Figure S2-S4), the solutions of complex 3 remained translucent throughout the $48 \mathrm{~h}$, with no visible precipitation. Complex 3 also presented a higher solubility in both medium, with and without FBS. In general, all complexes were more soluble in the presence of FBS. In all cases, a new 
absorption peak appeared around $237 \mathrm{~nm}$, which was ascribed to the interaction of the complexes with the medium. In the medium with FBS, these interactions could be observed thought the peak at around $250 \mathrm{~nm}$.

\subsection{Antibacterial Activity}

The antibacterial properties of complexes 1-4 were assessed based on the determination of the MIC values towards the Gram-positive S. aureus Newman and the Gram-negative E. coli ATCC25922. The MIC values obtained for the four complexes tested and auranofin are summarized in Table 2.

Complexes 3 and $\mathbf{4}$ inhibited S. aureus Newman growth, with estimated MIC values of $15.3 \mu \mathrm{g} / \mathrm{mL}$ and $14.7 \mu \mathrm{g} / \mathrm{mL}$, respectively, while complexes 1 and 2 did not inhibit the growth of $S$. aureus for concentrations $\leq 125 \mu \mathrm{g} / \mathrm{mL}$. However, complex 2 at $125 \mu \mathrm{g} / \mathrm{mL}$ reduced $65 \%$ of the $S$. aureus Newman growth (data not shown). Contrastingly, no $E$. coli growth inhibition was detected for the complexes tested at concentrations up to 125 $\mu \mathrm{g} / \mathrm{mL}$. Concentrations higher than $125 \mu \mathrm{g} / \mathrm{mL}$ resulted in the formation of precipitates during the assay and were not considered. Results indicate a higher antibacterial activity of complexes $\mathbf{3}$ and $\mathbf{4}$ towards Gram-positive bacteria.

The antibacterial activity of auranofin was also tested as a reference. Auranofin was very active in inhibiting the growth of the Gram-positive S. aureus Newman, with an estimated MIC of $0.2 \mu \mathrm{g} / \mathrm{mL}$ (Table 2). In contrast, the estimated MIC value for the Gram-negative E. coli ATCC 25922 was $35.6 \mu \mathrm{g} / \mathrm{mL}$ (Table 2). These results are in good agreement with previous reports that describe a high potency of auranofin against Gram-positive clinical isolates, with inhibitory activities in the range $0.12-2 \mu \mathrm{g} / \mathrm{mL}$ and higher MIC values for Gram-negative bacteria $(>16 \mu \mathrm{g} / \mathrm{mL})$ [56,57]. Similar conclusions on relative antibacterial activity of the complexes can be taken if one 
considers the estimated antibacterial activity of complexes and auranofin in terms of molar concentration instead of mass concentration, as complex $\mathbf{3}$ and auranofin molecular masses of 671.76 and $678.48 \mathrm{~g} / \mathrm{mol}$, respectively. Complexes $\mathbf{1}$ and $\mathbf{2}$ are isomers with identical molecular mass $(719.80 \mathrm{~g} / \mathrm{mol})$ while complex 4 has the highest molecular mass $823.95 \mathrm{~g} / \mathrm{mol}$.

Previous studies suggested that auranofin inhibits the bacterial TrxR, a protein essential for the maintenance of the thiol-redox homeostasis in some Gram-positive bacteria, including S. aureus [57]. Thiol-based redox metabolism is essential for several cellular processes, such as protection against reactive oxidative species, correct protein folding, and DNA synthesis [58]. In many organisms, glutathione (GSH) and GR function in parallel with thioredoxin (Trx) and thioredoxin reductase (TrxR), to provide the cells with a source of reducing equivalents [58]. Several Gram-positive bacteria lack the GRGSH system, making the Trx-TrxR system an interesting new target for antimicrobials $[57,58]$. However, recent reports have shown that TrxR is not the primary target of auranofin in bacteria [59]. In their study, Thangamani et al. observed that auranofin inhibited several biosynthetic pathways in bacteria including cell wall, DNA and protein synthesis, but no exact molecular target was found [59]. These authors also observed that the lower activity of auranofin against Gram-negative bacteria was not only due to the presence of GR-GSH system, but also due to the permeability barrier conferred by the outer membrane.

\subsection{Antifungal activity}

The antifungal activities of the complexes 1-4 towards the pathogenic strains $C$. glabrata CBS138 and C. albicans SC5134 were assessed using the microdilution method. The MIC values for the four compounds tested are presented in Table 3. 
Results show that complex 3 was able to inhibit $C$. glabrata CBS138 growth, with an estimated MIC of $7 \mu \mathrm{g} / \mathrm{mL}$. The other three complexes tested were unable to inhibit $C$. glabrata growth. However, complex 2 at $62.5 \mu \mathrm{g} / \mathrm{mL}$ reduced C. glabrata CBS138 growth by 54\% (data not shown). C. albicans SC5134 growth was not inhibited by the four complexes tested, although complex 3 at $62.5 \mu \mathrm{g} / \mathrm{mL}$ reduced C. albicans SC5134 growth by $87 \%$ (data not shown). These results indicate a higher antifungal activity of complex 3 towards Candida strains, with a higher inhibitory effect against C. glabrata strains.

The antifungal activity of auranofin was also tested against the clinical Candida spp. strains for comparison. Auranofin was very active in inhibiting the growth of the Candida spp. isolates tested, with MIC values of 7.9 and $15.3 \mu \mathrm{g} / \mathrm{mL}$ for C. albicans and $C$. glabrata, respectively (Table 3 ). Previous studies have also shown that auranofin inhibits the growth of several clinical Candida spp. isolates [60]. Chemogenomic profiling of Saccharomyces cerevisiae with auranofin revealed that mitochondrial proteins are the potential targets of this compound [60].

\subsection{Cytotoxic activity}

The cytotoxic activity of complexes 1-4 was evaluated against the ovarian A2780 and A2780cisR cancer cells, sensitive and resistant to cisplatin, respectively, as well as towards the fibroblast normal cell line V79. Auranofin and cisplatin were included in the assays for comparative purposes.

As depicted in Figure 11 and Table 4, all complexes displayed similar high cytotoxic activity against both the sensitive and the resistant cancer cell lines upon $48 \mathrm{~h}$ of exposure to the complexes. At shorter incubation times $(3 \mathrm{~h})$, all the complexes presented $\mathrm{IC}_{50}$ values higher than $100 \mu \mathrm{M}$, with the exception of $\mathbf{3}\left(\mathrm{IC}_{50}=64.2 \pm 15\right.$ 
$\mu \mathrm{M}$ ) (data not shown). These differences in the complexes cytotoxic activity became more evident after $24 \mathrm{~h}$ of incubation (Figure 11). In fact, at $24 \mathrm{~h}$, complex 1 was the least active complex of the series for all the cell lines studied, even when compared with its relative complex 2. Auranofin also exhibited potent antitumor activity in both cancer cell lines upon $48 \mathrm{~h}$ incubation (Table 4), in agreement with results previously reported for $\mathrm{A} 2780$ cells $[10,61]$. Upon $48 \mathrm{~h}$ incubation, the $\mathrm{IC}_{50}$ values determined for the gold complexes towards the cisplatin sensitive A2780 cells were in the same order of magnitude $(0.9-4.4 \mu \mathrm{M})$ as those obtained in this study for cisplatin $\left(\mathrm{IC}_{50}=3.6 \pm 1.3\right.$ $\mu \mathrm{M})$. However, in the resistant cell line $\mathrm{A} 280 \mathrm{cisR}$, the $\mathrm{IC}_{50}$ values of the complexes were remarkably lower, about one order of magnitude, when compared to cisplatin $\left(\mathrm{IC}_{50}\right.$ $=36 \pm 13 \mu \mathrm{M})$, which indicates the occurrence of less cross-resistance for the new complexes tested than for the reference drug. The precursor potassium gold(III) chloride $\left(\mathrm{KAuCl}_{4}\right)$ and the ligand potassium-1,1-dicyano-2,2-ethylenedithiolate $\left(\mathrm{K}_{2}(\mathrm{i}-\mathrm{mnt})\right.$ were also included in the study but displayed very low activity $\left(\mathrm{IC}_{50}>100 \mu \mathrm{M}\right)$ (data not shown). These results indicate that the coordination to the gold center resulted in a considerable improvement of the cytotoxic activity and neither the ligands nor the gold precursor seemed to be the active species responsible for the cytotoxicity.

A highly relevant point concerning viable pharmacological applications of anticancer drugs is their relatively high degree of specificity for cancer cells [62]. Thus, it is important to evaluate the cytotoxic activity of a prospective drug against a normal cell line. In this work, V79 fibroblasts were selected to evaluate the selectivity of the complexes against cancer cells (Table 4). The $\mathrm{IC}_{50}$ values calculated for the reference drugs cisplatin and auranofin in normal cells revealed auranofin as the more toxic compound towards these cells. These results highlight another potentially advantageous feature of the monoanionic gold bisdithiolate complexes under study in being less toxic 
to normal cells than the reference drug auranofin, while presenting similar toxicity to cisplatin.

\subsection{Production of ROS}

Several anticancer drugs act by inhibiting and suppressing cancer progression through ROS-mediated cell death [63]. ROS are highly reactive and extremely unstable molecules. Therefore, their detection relies on the measurement of the end products that are formed when these molecules react with particular substances. The potential induction of intracellular ROS by complexes 1-4 and the reference drugs in A2780 cells was analysed using the nitroblue tetrazolium (NBT) colorimetric assay and the $\mathrm{H}_{2}$ DCFDA fluorescent probe.

The NBT is the most sensitive probe for the detection of superoxide anion and is suitable for the detection of the early steps of oxidative stress by various treatments. As shown in Figure 12, the compounds were able to induce the generation of superoxide anions, detected with NBT. In fact, at concentrations above $20 \mu \mathrm{M}$, the formation of superoxide anion was evident for all the complexes. As superoxide is mostly produced within the mitochondria, it is possible that this organelle can mediate the cytotoxic effect of the compounds.

$\mathrm{H}_{2}$ DCFDA is one of the most widely used methods for directly measuring the redox state of a cell. Therefore, $\mathrm{H}_{2}$ DCFDA oxidation should be interpreted as an indication of the general cellular oxidative stress due to a variety of factors. However, some challenges for the use of $\mathrm{H}_{2}$ DCFDA have been discussed, including fluctuations in cellular antioxidants, different cellular permeability to the probe and, very importantly, the esterase activity that may vary among cells $[64,65]$. Hydrogen peroxide, hydroxyl radicals or peroxynitrite can be detected using the $\mathrm{H}_{2}$ DCFDA probe. The peroxynitrite 
anion $\left(\mathrm{ONOO}^{-}\right)$, a product of the reaction between superoxide anion and nitric oxide is a strong oxidant. Once protonated, $\mathrm{ONOOH}$ originates a highly reactive product that can induce the oxidation of thiol groups on proteins, thus affecting cellular metabolism. The effect of the complexes and the reference drugs on ROS production by A2780 cells, as well as the results from positive controls, are depicted in Figure 13-A. The formation of ROS was higher for $\mathbf{2}$ and $\mathbf{3}$ at concentrations above $20 \mu \mathrm{M}$, a trend similar to that obtained for the reference drugs auranofin and cisplatin. These observations are in agreement with previous reports on studies of the mechanism of action of these drugs $[66,67]$. In fact, inhibition of thiol enzymes by auranofin was shown to promote cell death through the activation of apoptosis and ROS accumulation [66]. Concerning cisplatin, it is well known that its cytotoxicity has been correlated to the generation of mitochondrial ROS that can promote a series of deleterious events and influence multiple metabolic functions which may ultimately lead to cell death [67].

To determine if the changes in ROS levels reflected a functional role of ROS in the compounds mode of action, the assays mentioned above were repeated using several ROS scavengers, namely sodium pyruvate, DMSO, and sodium bicarbonate. The former protects the cells from $\mathrm{H}_{2} \mathrm{O}_{2}$ damage [68], the latter enhances the decomposition of peroxynitrite [69], while DMSO traps the hydroxide radical $\mathrm{OH}^{\cdot}[70,71]$. The results presented in Figure 13-B suggest $\mathrm{H}_{2} \mathrm{O}_{2}$ as the ROS species involved in the mechanism of action of both complexes $\mathbf{2}$ and $\mathbf{3}$, and also of auranofin, although to a lesser extent. Despite complexes $\mathbf{2}$ and $\mathbf{3}$ exhibited similar cytotoxicity towards the cell lines under study, their ROS production profiles were distinct.

\subsection{Caspase assays}


Apoptotic cell death involves caspases, a family of cysteine proteases that play an essential role in apoptosis. Caspases function in a cascade of cleavage events that culminate in cell death. The initiator caspases, caspases-8 and -9 , activate the executioner's caspases-3, -6 and -7 , which cleave selected targets, enabling cell death. We explored the use of the active form of caspase- 3 and -7 for the detection of apoptotic events induced by the gold complexes 1-4 [72,73].

Zinc is an effective signalling regulator and has emerged as an important caspase regulator by direct inactivation of caspases. Zinc inhibits both the initiator and executioner apoptotic caspases by binding to the caspases zinc-binding sites [72,73].

As depicted in Figure 14, the ability of the complexes to activate caspase-3/7 correlated with their cytotoxicity. Complexes $\mathbf{2}$ and $\mathbf{3}$ showed the highest caspase activation activity, in contrast to $\mathbf{4}$, which we hypothesize to induce cell death by other mechanisms. Co-incubation with $\mathrm{Zn}^{2+}(50 \mu \mathrm{M})$ prevented the occurrence of apoptosis induced by the complexes.

\subsection{Complexes - DNA Interactions}

As previously mentioned, the monoanionic Au bisdithiolate complexes under study were found to exhibit square planar coordination geometry, which is similar to that of cisplatin. This is also the case of many monoanionic Au complexes of this type, leading to the proposal that they might share similar mechanisms of action through interaction with the DNA, a feature already observed for some gold(III) compounds [74]. In this context, we investigated whether the most promising complexes analysed in this study, complexes $\mathbf{3}$ and $\mathbf{4}$, were able to interact with and induce conformational changes in ФX174 supercoiled DNA, in vitro. As shown in Figure 15, cisplatin was able to alter, in a dose-dependent way, the electrophoretic mobilities of the nicked and supercoiled 
forms of DNA (top and lower bands in the gel, respectively), a feature characteristic of compounds with DNA intercalation or crosslinking abilities [75]. In contrast, none of the complexes were able to induce conformational changes in the DNA, following the same pattern observed for auranofin and as previously described [74]. These results demonstrate that the cytotoxic effect of these complexes is not mediated by their interaction with the DNA, suggesting instead a mechanism of action distinct from that of cisplatin.

\section{Conclusions}

Four homoleptic monoanionic Au bisdithiolate complexes (1-4), two of them structurally analysed for the first time, were characterized and evaluated as prospective therapeutic drugs. Complexes $\mathbf{3}$ and $\mathbf{4}$, where the unpaired electrons have density in $s p^{2}$ nitrogen atoms, were more reactive than complexes $\mathbf{1}$ and $\mathbf{2}$ that possess only nitrogen atoms in a nitrile group. In the case of complex $\mathbf{3}$, the reactivity of the $s p^{2}$ nitrogen is attenuated by the inductive effect of the nitrile group. These differences are also suggested by the cyclic voltammetry studies, that showed a more complex voltamogram in the case of $\left[\mathrm{Au}(\mathrm{qdt})_{2}\right]^{-}$, which can be ascribed to the presence of protonated species. The favourable occurrence of protonated species, especially in $\mathbf{3}$ and $\mathbf{4}$, would allow the molecules to be positively charged. In the case of complexes $\mathbf{1}$ and $\mathbf{2}$, the protonation effects are not present in $\mathrm{CV}$, although the change of the complex to a cationic state through a hydrolyzation (acid or basic medium) of the nitrile group, leading to the formation of primary amines, cannot be entirely excluded. The crystal structure analysis shows that all studied complexes can interact with surrounding molecules through strong $\mathrm{Au} \cdots \mathrm{S}$ and S $\cdots S$ interactions, and charge assisted hydrogen bonds. The present study demonstrates the potential of homoleptic bisdithiolate gold complexes as a novel 
approach in the design and development of new antibacterial, antifungal and antitumor agents.

Complex 3, the most redox-stable complex, presents very significant antimicrobial activity, both towards the Gram-positive $S$. aureus and towards the fungal pathogen $C$. glabrata. Complex 4 only presents antimicrobial activity against the Gram-positive $S$. aureus. This result suggests that the biological target(s) of the complex differs in prokaryotic and eukaryotic cells, and/or that the permeability of the two types of cells to the compounds is different. The isomeric complexes $\mathbf{1}$ and $\mathbf{2}$ have no antimicrobial activity towards either the bacterial or fungal strains tested. Nevertheless, they present differences in their cytotoxic activity in the ovarian cancer cells and the normal fibroblasts, as well as in their ability to induce ROS production. The dithiolate ligands play a significant role in the redox properties of the complexes, but as demonstrated by specific tests with $\mathrm{KAuCl}_{4}$ and $\mathrm{K}_{2}(i \text {-mnt })_{2}$, neither the ligands nor the gold precursor are active species responsible for the cytotoxicity.

In summary, the antimicrobial and antitumor activity of this type of Au bisdithiolate complexes was established against the Gram-positive $S$ aureus, the fungal species $C$. glabrata, and ovarian cancer cells, with promising results. The exact mechanism of action of these complexes is yet unknown; the targets are unidentified and the exact chemical nature of the active species responsible for their activity are still unclear.

Nevertheless, the properties of these complexes revealed in this study can provide a valuable platform for designing new derivatives with improved biological activities and can contribute to shed more light on the structure-activity relationships. Future studies will also focus on cell membrane permeability by these complexes to enlighten the mechanisms underlying their cytotoxicity. In addition, as superoxide is mostly produced within mitochondria, our results suggest that superoxide mediates the cytotoxic effect of 
the complexes. Although speculative at present, the implication of the mitochondria in the mechanism of action of the gold bisdithiolate complexes worth further investigation.

\section{Acknowledgments}

The kind gift of C. albicans SC5134 and C. glabrata CBS138 by Professor Nuno Mira from iBB is gratefully acknowledge. This work was supported by Fundação para a Ciência e Tecnologia (FCT) through contracts UID/MULTI/04349/2013, PTDC/BIAMIC/1615/2014, UID/BIO/04565/2019, PTDC/SAU/INF/29550/2017 and PTDC/QUIQIN/29834/2017.

\section{Competing interests}

The authors declare no conflict of interest. The funding source had no role on the study design, collection, analysis and data interpretation, writing and decision to submit the manuscript for publication.

\section{References:}

[1] World Health Organization, Global Action Plan on Antimicrobial Resistance, WHO Press, 2015. www.paprika-annecy.com (accessed November 27, 2018).

[2] L.B. Rice, Federal Funding for the Study of Antimicrobial Resistance in Nosocomial Pathogens: No ESKAPE, J. Infect. Dis. 197 (2008) 1079-1081. doi:10.1086/533452.

[3] M. Cavalheiro, P. Pais, M. Galocha, M.C. Teixeira, Host-Pathogen Interactions Mediated by MDR Transporters in Fungi: As Pleiotropic as it Gets!, Genes (Basel). 9 (2018) 332. doi:10.3390/genes9070332.

[4] M. Arnold, H.E. Karim-Kos, G. Byrnes, A. Antilla, J. Ferlay, A.G. Renehan, D. 
Forman, I. Soerjomataram, Recent trends in incidence of five common cancers in 26 European countries since 1988: Analysis of the European Cancer Observatory, Eur. J. Cancer. 51 (2015) 1164-1187. doi:10.1016/J.EJCA.2013.09.002.

[5] J. Klastersky, M. Aoun, Opportunistic infections in patients with cancer, Ann. Oncol. 15 (2004) iv329-iv335. doi:10.1093/annonc/mdh947.

[6] M. Plummer, C. de Martel, J. Vignat, J. Ferlay, F. Bray, S. Franceschi, Global burden of cancers attributable to infections in 2012: a synthetic analysis, Lancet Glob. Heal. 4 (2016) e609-e616. doi:10.1016/S2214-109X(16)30143-7.

[7] K. Hattar, C.P. Reinert, U. Sibelius, M.Y. Gökyildirim, F.S.B. Subtil, J. Wilhelm, B. Eul, G. Dahlem, F. Grimminger, W. Seeger, U. Grandel, Lipoteichoic acids from Staphylococcus aureus stimulate proliferation of human non-small-cell lung cancer cells in vitro., Cancer Immunol. Immunother. 66 (2017) 799-809. doi:10.1007/s00262-017-1980-4.

[8] A. Ramirez-Garcia, A. Rementeria, J.M. Aguirre-Urizar, M.D. Moragues, A. Antoran, A. Pellon, A. Abad-Diaz-de-Cerio, F.L. Hernando, Candida albicans and cancer: Can this yeast induce cancer development or progression?, Crit. Rev. Microbiol. 42 (2016) 181-193. doi:10.3109/1040841X.2014.913004.

[9] M.R. Felício, O.N. Silva, S. Gonçalves, N.C. Santos, O.L. Franco, Peptides with Dual Antimicrobial and Anticancer Activities., Front. Chem. 5 (2017) 5. doi:10.3389/fchem.2017.00005.

[10] I. Landini, A. Lapucci, A. Pratesi, L. Massai, C. Napoli, G. Perrone, P. Pinzani, L. Messori, E. Mini, S. Nobili, Selection and characterization of a human ovarian cancer cell line resistant to auranofin., Oncotarget. 8 (2017) 96062-96078. doi:10.18632/oncotarget.21708.

[11] C. Roder, M.J. Thomson, Auranofin: repurposing an old drug for a golden new 
age., Drugs R. D. 15 (2015) 13-20. doi:10.1007/s40268-015-0083-y.

[12] T. Zou, C.T. Lum, C.-N. Lok, J.-J. Zhang, C.-M. Che, Chemical biology of anticancer gold( iii ) and gold( i ) complexes, Chem. Soc. Rev. 44 (2015) 87868801. doi:10.1039/C5CS00132C.

[13] Z.H. Siddik, Cisplatin: mode of cytotoxic action and molecular basis of resistance, Oncogene. 22 (2003) 7265-7279. doi:10.1038/sj.onc.1206933.

[14] G. Housman, S. Byler, S. Heerboth, K. Lapinska, M. Longacre, N. Snyder, S. Sarkar, Drug resistance in cancer: an overview., Cancers (Basel). 6 (2014) 17691792. doi:10.3390/cancers6031769.

[15] E.I. Stiefel, Dithiolene chemistry: synthesis, properties, and applications, Wiley, 2004.

[16] Z.H. Chohan, A.U. Shaikh, C.T. Supuran, In-vitro Antibacterial, Antifungal and cytotoxic activity of cobalt (II), copper (II), nickel (II) and zinc (II) complexes with furanylmethyl- and thienylmethyl-dithiolenes: [1, 3-dithiole- 2-one and 1,3dithiole-2-thione], J. Enzyme Inhib. Med. Chem. 21 (2006) 733-740. doi:10.1080/14756360600810308.

[17] A. Pintus, M.C. Aragoni, M.A. Cinellu, L. Maiore, F. Isaia, V. Lippolis, G. Orrù, E. Tuveri, A. Zucca, M. Arca, [Au(pyb-H)(mnt)]: A novel gold(III) 1,2dithiolene cyclometalated complex with antimicrobial activity (pyb-H = Cdeprotonated 2-benzylpyridine; $m n t=1,2$-dicyanoethene-1,2-dithiolate), J. Inorg. Biochem. 170 (2017) 188-194. doi:10.1016/J.JINORGBIO.2017.02.015.

[18] D. Belo, J. Morgado, E.B. Lopes, I.C. Santos, S. Rabaça, M.T. Duarte, V. Gama, R.T. Henriques, M. Almeida, Synthesis and characterisation of charge transfer salts based on Au(dcdmp)2 and TTF type donors, Synth. Met. 102 (1999) 17511752. doi:10.1016/S0379-6779(98)00400-7. 
[19] A.I.S. Neves, I.C. Santos, D. Belo, M. Almeida, Cation and ligand roles in the coordination of FeIII bisdithiolene complexes; the crystal structures of (BrBzPy)2[Fe(qdt)2]2 and [Fe( $\alpha$-tpdt)2]22- salts, CrystEngComm. (2009) 10461053. doi:10.1039/b813242a.

[20] D. Belo, C. Rodrigues, I.C. Santos, S. Silva, T. Eusébio, E.B. Lopes, J. V. Rodrigues, M.J. Matos, M. Almeida, M.T. Duarte, R.T. Henriques, Synthesis, crystal structure and magnetic properties of bis(3,4;3',4'-ethylenedithio $) 2,2^{\prime}, 5,5^{\prime}-$ tetrathiafulvalene-bis(cyanoimidodithiocarbonate)aurate(III), (bedt$\mathrm{ttf})[\mathrm{Au}(\mathrm{cdc}) 2], \quad$ Polyhedron. $\quad 25 \quad$ (2006) 1209-1214. doi:10.1016/J.POLY.2005.09.001.

[21] R.A.L. Silva, A.I.S. Neves, E.B. Lopes, I.C. Santos, J.T. Coutinho, L.C.J. Pereira, C. Rovira, M. Almeida, D. Belo, ( $\alpha$-DT-TTF $)_{2}\left[\mathrm{Au}(\mathrm{mnt})_{2}\right]$ : A Weakly Disordered Molecular Spin-Ladder System, Inorg. Chem. 52 (2013) 5300-5306. doi:10.1021/ic400246y.

[22] R.A.L. Silva, I.C. Santos, J. Wright, J.T. Coutinho, L.C.J. Pereira, E.B. Lopes, S. Rabaça, J. Vidal-Gancedo, C. Rovira, M. Almeida, D. Belo, Dithiophene-TTF Salts; New Ladder Structures and Spin-Ladder Behavior, Inorg. Chem. 54 (2015) 7000-7006. doi:10.1021/acs.inorgchem.5b01013.

[23] A. Davison, N. Edelstein, R.H. Holm, A.H. Maki, The Preparation and Characterization of Four-Coordinate Complexes Related by Electron-Transfer Reactions, Inorg. Chem. 2 (1963) 1227-1232. doi:10.1021/ic50010a031.

[24] B.G. Werden, E. Billig, H.B. Gray, Transition Metal Complexes Containing 1,1Dicyanoethylene-2,2-dithiolate, Inorg. Chem. $5 \quad$ (1966) 78-81. doi:10.1021/ic50035a019.

[25] F.A. Cotton, J.A. McCleverty, Transition metal complexes of the N- 
cyanocarbimate ion, [S2C2N2]2-, Inorg. Chem. 6 (1967) 229-232. doi:10.1021/ic50048a008.

[26] X. Ribas, M. Mas-Torrent, C. Rovira, J. Veciana, J.C. Dias, H. Alves, E.B. Lopes, M. Almeida, K. Wurst, Molecular compounds based on DT-TTF and $\mathrm{Au}(\mathrm{cdc}) 2$ complex. Structural, magnetic and electrical properties, Polyhedron. 22 (2003) 2415-2422. doi:10.1016/S0277-5387(03)00255-9.

[27] L.J. Theriot, K.K. Ganguli, S. Kavarnos, I. Bernal, Metal complexes of 2,3quinoxalinedithiol, J. Inorg. Nucl. Chem. 31 (1969) 3133-3140. doi:10.1016/0022-1902(69)80096-5.

[28] K.K. Ganguli, G.O. Carlisle, H.J. Hu, L.J. Theriot, I. Bernal, Cobalt and iron complexes of 2,3-quinoxalinedithiol, J. Inorg. Nucl. Chem. 33 (1971) 35793581. doi:10.1016/0022-1902(71)80683-8.

[29] D. Simão, E.B. Lopes, I.C. Santos, V. Gama, R.T. Henriques, M. Almeida, Charge transfer salts based on $\mathrm{Cu}(\mathrm{qdt}) 2$, Ni(qdt)2 and Au(qdt)2 anions, Synth. Met. 102 (1999) 1613-1614. doi:10.1016/S0379-6779(98)00445-7.

[30] E.S. DUTHIE, L.L. LORENZ, Staphylococcal Coagulase: Mode of Action and Antigenicity, Microbiology. 6 (1952) 95-107. doi:10.1099/00221287-6-1-2-95.

[31] T.D. Minogue, H.A. Daligault, K.W. Davenport, K.A. Bishop-Lilly, S.M. Broomall, D.C. Bruce, P.S. Chain, O. Chertkov, S.R. Coyne, T. Freitas, K.G. Frey, H.S. Gibbons, J. Jaissle, C.L. Redden, C.N. Rosenzweig, Y. Xu, S.L. Johnson, Complete Genome Assembly of Escherichia coli ATCC 25922, a Serotype O6 Reference Strain., Genome Announc. 2 (2014) e00969-14. doi:10.1128/genomeA.00969-14.

[32] A. Borst, M.T. Raimer, D.W. Warnock, C.J. Morrison, B.A. Arthington-Skaggs, Rapid acquisition of stable azole resistance by Candida glabrata isolates 
obtained before the clinical introduction of fluconazole., Antimicrob. Agents Chemother. 49 (2005) 783-787. doi:10.1128/AAC.49.2.783-787.2005.

[33] A.M. Gillum, E.Y. Tsay, D.R. Kirsch, Isolation of the Candida albicans gene for orotidine-5'-phosphate decarboxylase by complementation of S. cerevisiae ura3 and E. coli pyrF mutations., Mol. Gen. Genet. 198 (1984) 179-182.

[34] J.P. Costa, M.J.F. Pinheiro, S.A. Sousa, A.M. Botelho do Rego, F. Marques, M.C. Oliveira, J.H. Leitão, N. P Mira, M.F. N N Carvalho, Antimicrobial Activity of Silver Camphorimine Complexes against Candida Strains., Antibiot. (Basel, Switzerland). 8 (2019) E144. doi:10.3390/antibiotics8030144.

[35] A. Altomare, M.C. Burla, M. Camalli, G.L. Cascarano, C. Giacovazzo, A. Guagliardi, A.G.G. Moliterni, G. Polidori, R. Spagna, SIR 97: a new tool for crystal structure determination and refinement, J. Appl. Crystallogr. 32 (1999) 115-119. doi:10.1107/S0021889898007717.

[36] G.M. Sheldrick, SHELXL-97 program for crystal structure refinement, University of Gottingen, Gottingen, Germany, 1997.

[37] L.J. Farrugia, WinGX suite for small-molecule single-crystal crystallography, J. Appl. Crystallogr. 32 (1999) 837-838. doi:10.1107/S0021889899006020.

[38] L.J. Farrugia, IUCr, ORTEP -3 for Windows - a version of ORTEP -III with a Graphical User Interface (GUI), J. Appl. Crystallogr. 30 (1997) 565. doi:10.1107/S0021889897003117.

[39] W.M.H. Ren J, Liang W, Crystal and electronic structure analysis using CAESAR, PrimeColor Software Inc., Cary, North Carolina, USA, 1998.

[40] R. Hoffmann, An Extended Hückel Theory. I. Hydrocarbons, J. Chem. Phys. 39 (1963) 1397-1412. doi:10.1063/1.1734456.

[41] M.-H. Whangbo, R. Hoffmann, The band structure of the tetracyanoplatinate 
chain, J. Am. Chem. Soc. 100 (1978) 6093-6098. doi:10.1021/ja00487a020.

[42] M.-H. Whangbo, R. Hoffmann, R.B. Woodward, Conjugated One and Two Dimensional Polymers, Proc. R. Soc. A Math. Phys. Eng. Sci. 366 (1979) $23-46$. doi:10.1098/rspa.1979.0037.

[43] E. Canadell, E.-I. Rachidi, S. Ravy, J.P. Pouget, L. Brossard, J.P. Legros, On the band electronic structure of $\mathrm{X}[\mathrm{M}(\mathrm{dmit}) 2] 2(\mathrm{X}=\mathrm{TTF},(\mathrm{CH} 3) 4 \mathrm{~N} ; \mathrm{M}=\mathrm{Ni}, \mathrm{Pd})$ molecular conductors and superconductors, J. Phys. 50 (1989) 2967-2981. doi:10.1051/jphys:0198900500190296700ï.

[44] J.M.S. Cardoso, A.M. Galvão, S.I. Guerreiro, J.H. Leitão, A.C. Suarez, M.F.N.N. Carvalho, Antibacterial activity of silver camphorimine coordination polymers., Dalton Trans. 45 (2016) 7114-7123. doi:10.1039/c6dt00099a.

[45] L.G. Alves, P.F. Pinheiro, J.R. Feliciano, D.P. Dâmaso, J.H. Leitão, A.M. Martins, Synthesis, antimicrobial activity and toxicity to nematodes of cyclam derivatives, Int. J. Antimicrob. Agents. 49 (2017) 646-649. doi:10.1016/j.ijantimicag.2017.03.002.

[46] M.F.N.N. Carvalho, S. Leite, J.P. Costa, A.M. Galvão, J.H. Leitão, Ag(I) camphor complexes: antimicrobial activity by design., J. Inorg. Biochem. 199 (2019) 110791. doi:10.1016/j.jinorgbio.2019.110791.

[47] R.J.W. Lambert, J. Pearson, Susceptibility testing: accurate and reproducible minimum inhibitory concentration (MIC) and non-inhibitory concentration (NIC) values, J. Appl. Microbiol. 88 (2000) 784-790. doi:10.1046/j.13652672.2000.01017.x.

[48] M.C. Arendrup, M. Cuenca-Estrella, C. Lass-Flörl, W. Hope, EUCAST technical note on the EUCAST definitive document EDef 7.2: method for the determination of broth dilution minimum inhibitory concentrations of antifungal 
agents for yeasts EDef 7.2 (EUCAST-AFST), Clin. Microbiol. Infect. 18 (2012) E246-E247. doi:10.1111/J.1469-0691.2012.03880.X.

[49] J.M.S. Cardoso, S.I. Guerreiro, A. Lourenço, M.M. Alves, M.F. Montemor, N.P. Mira, J.H. Leitão, M.F.N.N. Carvalho, Ag(I) camphorimine complexes with antimicrobial activity towards clinically important bacteria and species of the Candida genus, PLoS One. $12 \quad$ (2017) 0177355. doi:10.1371/journal.pone.0177355.

[50] N. Esfandiari, R.K. Sharma, R.A. Saleh, A.J. Thomas, A. Agarwal, Utility of the nitroblue tetrazolium reduction test for assessment of reactive oxygen species production by seminal leukocytes and spermatozoa., J. Androl. 24 (2003) 862870.

[51] I. Fridovich, Superoxide Anion Radical $\left(\mathrm{O}^{-}{ }_{2}\right)$, Superoxide Dismutases, and Related Matters, J. Biol. Chem. 272 (1997) 18515-18517. doi:10.1074/jbc.272.30.18515.

[52] B. Kalyanaraman, V. Darley-Usmar, K.J.A. Davies, P.A. Dennery, H.J. Forman, M.B. Grisham, G.E. Mann, K. Moore, L.J. Roberts, H. Ischiropoulos, H. Ischiropoulos, Measuring reactive oxygen and nitrogen species with fluorescent probes: challenges and limitations., Free Radic. Biol. Med. 52 (2012) 1-6. doi:10.1016/j.freeradbiomed.2011.09.030.

[53] C. Francisco, S. Gama, F. Mendes, F. Marques, I. Cordeiro dos Santos, A. Paulo, I. Santos, J. Coimbra, E. Gabano, M. Ravera, Pt(ii) complexes with bidentate and tridentate pyrazolyl-containing chelators: synthesis, structural characterization and biological studies, Dalt. Trans. $40 \quad$ (2011) 5781-5792. doi:10.1039/c0dt01785j.

[54] D. Coucouvanis, The Chemistry of the Dithioacid and 1,1-Dithiolate Complexes, 
in: Prog. Inorg. Chem., John Wiley \& Sons, Ltd, 1970: pp. 233-371. doi:10.1002/9780470166123.ch4.

[55] R. Williams, E. Billig, J.H. Waters, H.B. Gray, The Toluenedithiolate and Maleonitriledithiolate Square-Matrix Systems, J. Am. Chem. Soc. 88 (1966) 4350. doi:10.1021/ja00953a009.

[56] L. Aguinagalde, R. Díez-Martínez, J. Yuste, I. Royo, C. Gil, Í. Lasa, M. MartínFontecha, N.I. Marín-Ramos, C. Ardanuy, J. Liñares, P. García, E. García, J.M. Sánchez-Puelles, Auranofin efficacy against MDR Streptococcus pneumoniae and Staphylococcus aureus infections, J. Antimicrob. Chemother. 70 (2015) 2608-2617. doi:10.1093/jac/dkv163.

[57] M.B. Harbut, C. Vilchèze, X. Luo, M.E. Hensler, H. Guo, B. Yang, A.K. Chatterjee, V. Nizet, W.R. Jacobs, P.G. Schultz, F. Wang, F. Wang, Auranofin exerts broad-spectrum bactericidal activities by targeting thiol-redox homeostasis., Proc. Natl. Acad. Sci. U. S. A. 112 (2015) 4453-4458. doi:10.1073/pnas.1504022112.

[58] J. Lu, A. Holmgren, The thioredoxin antioxidant system, Free Radic. Biol. Med. 66 (2014) 75-87. doi:10.1016/j.freeradbiomed.2013.07.036.

[59] S. Thangamani, H. Mohammad, M.F.N. Abushahba, T.J.P. Sobreira, V.E. Hedrick, L.N. Paul, M.N. Seleem, Antibacterial activity and mechanism of action of auranofin against multi-drug resistant bacterial pathogens., Sci. Rep. 6 (2016) 22571. doi:10.1038/srep22571.

[60] S. Thangamani, M. Maland, H. Mohammad, P.E. Pascuzzi, L. Avramova, C.M. Koehler, T.R. Hazbun, M.N. Seleem, Repurposing Approach Identifies Auranofin with Broad Spectrum Antifungal Activity That Targets Mia40-Erv1 Pathway., Front. Cell. $\quad$ Infect. Microbiol. $\quad 7 \quad$ (2017) 4. 
doi:10.3389/fcimb.2017.00004.

[61] C. Marzano, V. Gandin, A. Folda, G. Scutari, A. Bindoli, M.P. Rigobello, Inhibition of thioredoxin reductase by auranofin induces apoptosis in cisplatinresistant human ovarian cancer cells, Free Radic. Biol. Med. 42 (2007) 872-881. doi:10.1016/J.FREERADBIOMED.2006.12.021.

[62] M. V Blagosklonny, Analysis of FDA approved anticancer drugs reveals the future of cancer therapy., Cell Cycle . 3 (2004) 1035-1042.

[63] X. Xu, Z. Dang, T. Sun, S. Zhang, H. Zhang, The role of reactive oxygen species in screening anticancer agents, Cancer Transl. Med. 4 (2018) 35-38. doi:10.4103/ctm.ctm_6_18.

[64] W. Jakubowski, G. Bartosz, 2,7-dichlorofluorescin oxidation and reactive oxygen species: What does it measure?, Cell Biol. Int. 24 (2000) 757-760. doi:10.1006/cbir.2000.0556.

[65] Y. Zhang, M. Dai, Z. Yuan, Methods for the detection of reactive oxygen species, Anal. Methods. 10 (2018) 4625-4638. doi:10.1039/c8ay01339j.

[66] H. Hwang-Bo, J.-W. Jeong, M.H. Han, C. Park, S.-H. Hong, G.-Y. Kim, S.-K. Moon, J. Cheong, W.-J. Kim, Y.H. Yoo, Y.H. Choi, Auranofin, an inhibitor of thioredoxin reductase, induces apoptosis in hepatocellular carcinoma Hep3B cells by generation of reactive oxygen species, Gen. Physiol. Biophys. 36 (2017) 117128. doi:10.4149/gpb_2016043.

[67] Y.-M. Choi, H.-K. Kim, W. Shim, M.A. Anwar, J.-W. Kwon, H.-K. Kwon, H.J. Kim, H. Jeong, H.M. Kim, D. Hwang, H.S. Kim, S. Choi, Mechanism of Cisplatin-Induced Cytotoxicity Is Correlated to Impaired Metabolism Due to Mitochondrial ROS Generation., PLoS One. $10 \quad$ (2015) e0135083. doi:10.1371/journal.pone.0135083. 
[68] X. Wang, E. Perez, R. Liu, L.-J. Yan, R.T. Mallet, S.-H. Yang, Pyruvate protects mitochondria from oxidative stress in human neuroblastoma SK-N-SH cells., Brain Res. 1132 (2007) 1-9. doi:10.1016/j.brainres.2006.11.032.

[69] A.U. Khan, D. Kovacic, A. Kolbanovskiy, M. Desai, K. Frenkel, N.E. Geacintov, The decomposition of peroxynitrite to nitroxyl anion (NO-) and singlet oxygen in aqueous solution., Proc. Natl. Acad. Sci. U. S. A. 97 (2000) 2984-2989. doi:10.1073/pnas.050587297.

[70] C.F. Brayton, Dimethyl sulfoxide (DMSO): a review., Cornell Vet. 76 (1986) 61-90.

[71] N.C. Santos, J. Figueira-Coelho, J. Martins-Silva, C. Saldanha, Multidisciplinary utilization of dimethyl sulfoxide: pharmacological, cellular, and molecular aspects., Biochem. Pharmacol. 65 (2003) 1035-1041. doi:10.1016/s00062952(03)00002-9.

[72] D.K. Perry, M.J. Smyth, H.R. Stennicke, G.S. Salvesen, P. Duriez, G.G. Poirier, Y.A. Hannun, Zinc is a potent inhibitor of the apoptotic protease, caspase-3. A novel target for zinc in the inhibition of apoptosis., J. Biol. Chem. 272 (1997) 18530-18533. doi:10.1074/jbc.272.30.18530.

[73] S.J. Eron, D.J. MacPherson, K.B. Dagbay, J.A. Hardy, Multiple Mechanisms of Zinc-Mediated Inhibition for the Apoptotic Caspases-3, -6, -7, and -8., ACS Chem. Biol. 13 (2018) 1279-1290. doi:10.1021/acschembio.8b00064.

[74] C.K. Mirabelli, C.-M. Sung, J.P. Zimmerman, D.T. Hill, S. Mong, S.T. Crooke, Interactions of gold coordination complexes with DNA, Biochem. Pharmacol. 35 (1986) 1427-1433. doi:10.1016/0006-2952(86)90106-1.

[75] G. Cohen, W. Bauer, J. Barton, S. Lippard, Binding of cis- and transdichlorodiammineplatinum(II) to DNA: evidence for unwinding and shortening 
of the double helix, Science (80-. ). 203 (1979) 1014-1016.

doi:10.1126/science.370979. 
Table 1 - Oxidation potentials of complexes 1-2 and 4. ${ }^{\S}$

\begin{tabular}{|c|c|c|c|c|}
\hline Complex & $\begin{array}{c}\mathbf{E}_{\mathbf{c}} \\
(\mathrm{mV})\end{array}$ & $\begin{array}{c}\mathbf{E}_{\mathrm{a}} \\
(\mathrm{mV})\end{array}$ & $\begin{array}{c}\mathrm{E}_{1 / 2} \\
(\mathrm{mV})\end{array}$ & $\begin{array}{r}\mathrm{E}_{1 / 2} \mathrm{Fc} \\
(\mathrm{mV})\end{array}$ \\
\hline 1 & -861 & -724 & -793 & 143 \\
\hline 2 & -829 & - & - & 155 \\
\hline 4 & -701 & 901 & - & 135 \\
\hline
\end{tabular}

${ }^{\S}$ The studies were performed under the same experimental conditions using working and counter Pt electrodes, $\mathrm{Ag} / \mathrm{AgNO}_{3}\left(10^{-3} \mathrm{M}\right)$ as the reference electrode and $\mathrm{CH}_{3} \mathrm{CN}$ as solvent. The scan rate used was $100 \mathrm{mV} \cdot \mathrm{s}^{-1} \cdot \mathrm{E}_{1 / 2}\left(v s . \mathrm{Ag} / \mathrm{AgNO}_{3}\right)=\mathrm{E}_{1 / 2}(\mathrm{vs} . \mathrm{Ag} / \mathrm{AgCl})-300 \mathrm{mV}$. The redox potentials were normalized relatively to the $\mathrm{Fc} / \mathrm{Fc}^{+}$couple, which was used as an internal reference. Half-wave potentials are given by $E_{1 / 2}=\left(E_{a}+E p_{c}\right) / 2$. 
Table 2- Estimated minimum inhibitory concentration (MIC) of complexes 1-4, and auranofin, towards the Gram-negative E. coli ATCC 25922 and the Gram-positive $S$. aureus Newman. Results are the mean \pm SD of three independent experiments done with two replicates.

\begin{tabular}{ccc}
\hline \multirow{2}{*}{ Complex } & \multicolumn{2}{c}{ MIC $(\mu \mathrm{g} / \mathrm{mL})$} \\
\cline { 2 - 3 } & E. coli ATCC25922 & S. aureus Newman \\
\hline $\mathbf{1}$ & $>125$ & $>125$ \\
$\mathbf{3}$ & $>125$ & $>125$ \\
$\mathbf{4}$ & $>125$ & $15.3 \pm 1.3$ \\
& $>125$ & $14.7 \pm 0.9$ \\
Auranofin & $35.6 \pm 0.5$ & 0.2 \\
\hline
\end{tabular}


Table 3 - Estimated minimum inhibitory concentration (MIC) of complexes $\mathbf{1 - 4}$, and auranofin, towards $C$. albicans SC5134 and $C$ glabrata CBS138 strains. Results are the mean \pm SD of three independent experiments done with two replicates.

\begin{tabular}{ccc}
\hline Complex & $\begin{array}{c}\text { C. albicans SC5134 } \\
\text { MIC }(\boldsymbol{\mu g} / \mathbf{m L})\end{array}$ & $\begin{array}{c}\text { C. glabrata CBS138 } \\
\text { MIC }(\boldsymbol{\mu g} / \mathbf{m L})\end{array}$ \\
\hline $\mathbf{1}$ & $>125$ & $>125$ \\
$\mathbf{3}$ & $>125$ & $>125$ \\
$\mathbf{4}$ & $>62.5$ & $7.0 \pm 0.8$ \\
& $>62.5$ & $>62.5$ \\
Auranofin & $7.9 \pm 0.6$ & $15.3 \pm 0.4$ \\
\hline
\end{tabular}


Table $4-\mathrm{IC}_{50}$ values $(\mu \mathrm{M})$ determined after $48 \mathrm{~h}$ incubation for the complexes and reference drugs in the ovarian cancer cells A2780 and A2780cisR and the normal V79 fibroblasts. Results are shown as the mean \pm SD of two independent experiments done with six replicates.

\begin{tabular}{ccccc}
\hline Compounds & A2780 & A2780cisR & V79 & SI* \\
\hline $\boldsymbol{1}$ & $4.4 \pm 1.3$ & $5.5 \pm 1.5$ & $26 \pm 4.8$ & 6.0 \\
$\mathbf{2}$ & $1.5 \pm 0.5$ & $2.3 \pm 1.0$ & $2.4 \pm 0.7$ & 1.6 \\
$\mathbf{3}$ & $0.9 \pm 0.2$ & $1.7 \pm 0.5$ & $3.4 \pm 1.0$ & 3.8 \\
$\mathbf{4}$ & $1.2 \pm 0.3$ & $1.3 \pm 0.4$ & $5.3 \pm 1.1$ & 4.4 \\
\hline Auranofin & $0.4 \pm 0.3$ & $0.5 \pm 0.17$ & $0.7 \pm 0.3$ & 1.5 \\
Cisplatin & $3.6 \pm 1.3$ & $36 \pm 13$ & $6.7 \pm 2.7$ & 1.9 \\
\hline
\end{tabular}

*SI= the selectivity index calculated as $\mathrm{IC}_{50}(\mathrm{~V} 79) / \mathrm{IC}_{50}(\mathrm{~A} 2780)$. 
Figure 1 - Molecular structures of the complexes under study: $\left[\mathrm{Au}(\mathrm{mnt})_{2}\right]^{-}$(where mnt $=$ 1,1-dicyanoethylene-2,2'-dithiolate $)(\mathbf{1}), \quad\left[\mathrm{Au}(i \text {-mnt })_{2}\right]^{-} \quad($ where $\quad i$-mnt $=2,2-$ dicyanoethylene-1,1-dithiolate) (2), $\left[\mathrm{Au}(\mathrm{cdc})_{2}\right]^{-}$(where $\mathrm{cdc}=$ cyanodithioimido carbonate) (3) and [Au(qdt)2 $]^{-}$(where qdt = quinoxaline-2,3-dithiolate) (4).

Figure 2 - ORTEP top and side views of the monoanionic units in the crystal structure of a) TBA[Au(cdc) 2$](3)$ and b-c) TPP $\left[\mathrm{Au}(\mathrm{qdt})_{2}\right](\mathbf{4})$, with thermal ellipsoids drawn at $50 \%$ probability level.

Figure 3 - Crystal structure of TBA[Au(cdc $\left.)_{2}\right](3)$ viewed along $a$.

Figure 4 - Detail of an anionic chain in the crystal structure of TBA[Au(cdc $\left.)_{2}\right](3)$.

Figure 5 - Crystal structure of TPP[Au(qdt) $\left.)_{2}\right](4)$, viewed along $b$.

Figure 6 - Detail showing the possible intermolecular interactions in complexes 1-4: a) $S \cdots S$ and $N \cdots S$, b) $\pi-\pi$, c) $S \cdots A u$, d) $C-H \cdots N$, e) $C-H \cdots S$ and f) $C-H \cdots N$.

Figure 7 - Details of the relative shape and size of the anions electronic cloud in the crystal structures of complexes 1-4: a) $\left[\mathrm{Au}(\mathrm{mnt})_{2}\right]^{-}$, b) $\left.\left[\mathrm{Au}(i-\mathrm{mnt})_{2}\right]^{-}, \mathrm{c}\right)\left[\mathrm{Au}(\mathrm{cdc})_{2}\right]^{-}$and d) $\left[\mathrm{Au}(\mathrm{qdt})_{2}\right]^{-}$.

Figure 8 - HOMO schematic representation of complexes 1-4: a) $\left[\mathrm{Au}(\mathrm{mnt})_{2}\right]^{-}$, b) $\left.\left[\mathrm{Au}(i-\mathrm{mnt})_{2}\right]^{-}, \mathrm{c}\right)\left[\mathrm{Au}(\mathrm{cdc})_{2}\right]^{-}$and d) $\left[\mathrm{Au}(\mathrm{qdt})_{2}\right]^{-}$.

Figure 9 - Cyclic voltammograms of compounds 1, 2 and 4, in acetonitrile $\left(1 \times 10^{-3} \mathrm{M}\right)$ with $n-\mathrm{Bu}_{4} \mathrm{NPF}_{6}\left(1 \times 10^{-1} \mathrm{M}\right)$ as the supporting electrolyte, at room temperature, and at a scan rate $v=100 \mathrm{mV} / \mathrm{s}$.

Figure 10 - UV-Vis spectra of complex 3 in DMSO solution (a), in phenol red-free DMEM/F12 medium medium in the absence (b) and presence of FBS (c), at $0 \mathrm{~h}\left(\mathrm{~T}_{0}\right), 3 \mathrm{~h}$ $\left(\mathrm{T}_{3}\right), 24 \mathrm{~h}\left(\mathrm{~T}_{24}\right)$ and $48 \mathrm{~h}\left(\mathrm{~T}_{48}\right)$. 
Figure 11 - Cytotoxic activity, expressed as the $\mathrm{IC}_{50}$ values for complexes 1-4 towards the ovarian cancer cell lines A2780 and A2780cisR, and the V79 fibroblast cell line, determined after 24 and $48 \mathrm{~h}$ incubation. Data are shown as the (mean $\pm \mathrm{SD}$ ) of at least two independent experiments done with six replicates.

Figure 12- Superoxide production, using the NBT assay, by A2780 cells upon $3 \mathrm{~h}$ exposure to the indicated concentrations of complexes 1-4 and reference drugs auranofin (AUR) and cisplatin (cisPt) at 10, 20 and $50 \mu \mathrm{M}$. Results are mean \pm SD of two independent experiments done with four replicates.

Figure 13- ROS production based on 2', 7' -dichlorofluorescein (DCF) formation, by A2780 cells upon $3 \mathrm{~h}$ exposure to the complexes $\mathbf{1 - 4}$ and the reference drugs cisplatin (cisPt) and auranofin (AUR), in the absence (A) or presence (B) of the ROS scavengers sodium bicarbonate (SB), sodium pyruvate (SP) and DMSO. Results in relative fluorescence units are mean \pm SD of two independent experiments done with four replicates. $\mathrm{H}_{2} \mathrm{O}_{2}$ was used as positive control. Controls (Ctrl) consisting of cells incubated in the absence of complexes were also carried out in the absence (A) or presence (B) of ROS scavengers.

Figure 14- Caspase -3 and -7 activity in A2780 cells, upon $24 \mathrm{~h}$ exposure to the indicated concentrations of complexes 1-4 (corresponding to their $\mathrm{IC}_{50}$ ), in the absence or presence of $\mathrm{Zn}^{2+}(50 \mu \mathrm{M})$. Complexes $\mathbf{2}$ and $\mathbf{3}$, but not $\mathbf{4}$, induce apoptosis in A2780 cells. $\mathrm{Zn}^{2+}$ prevented apoptosis induced by the complexes. The apoptotic effect was evaluated by Caspase-Glo®3/7 assay. Data was obtained from three replicates per assay and was expressed as the mean $\pm \mathrm{SD}$, in relative fluorescence units.

Figure 15- Photographs of agarose gels loaded with samples of supercoiled $\phi X 174$ DNA incubated for $24 \mathrm{~h}$ at $37{ }^{\circ} \mathrm{C}$ in phosphate buffer ( $\mathrm{pH} 7.2$ ) with the indicated concentrations of cisplatin, auranofin, and complexes $\mathbf{3}$ or $\mathbf{4}$, obtained after 
electrophoresis for $3 \mathrm{~h}$ at $90 \mathrm{~V}$ and GelRed ${ }^{\circledR}$ staining. Controls using supercoiled $\phi \mathrm{X} 174$

DNA incubated with (Cont DMSO) and without DMSO (Cont DNA) are also shown. 


\section{Figure 1}
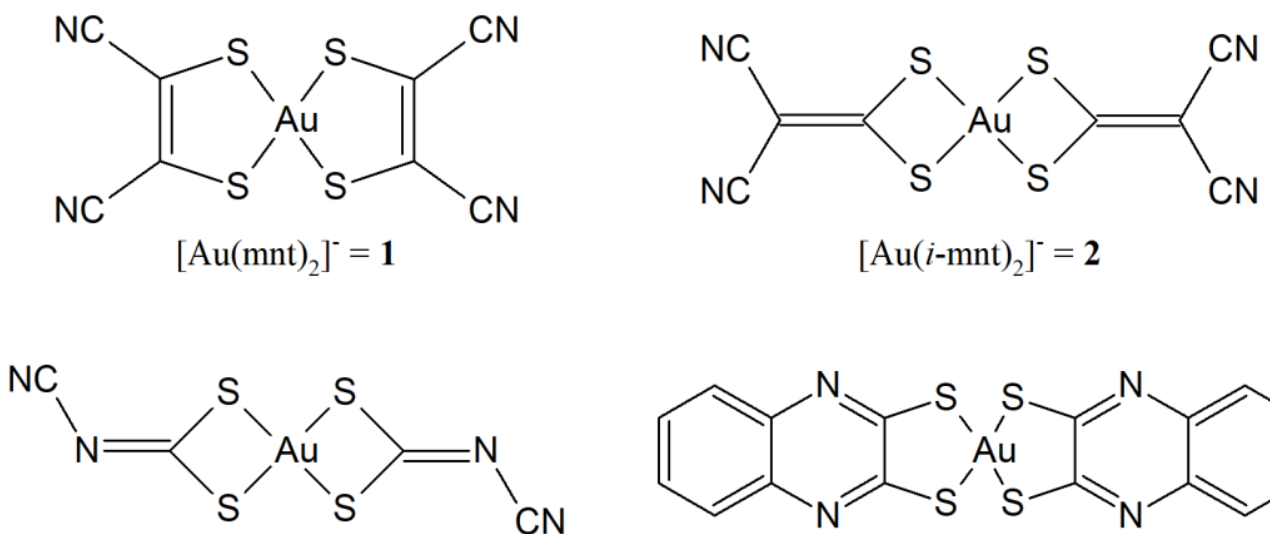

$\left[\mathrm{Au}(\mathrm{cdc})_{2}\right]^{-}=\mathbf{3}$<smiles>c1ccc2nc3c(nc2c1)S[Ge]1(S3)Sc2nc3ccccc3nc2S1</smiles>

$\left[\mathrm{Au}(\mathrm{qdt})_{2}\right]^{-}=\mathbf{4}$ 
Figure 2

(a)
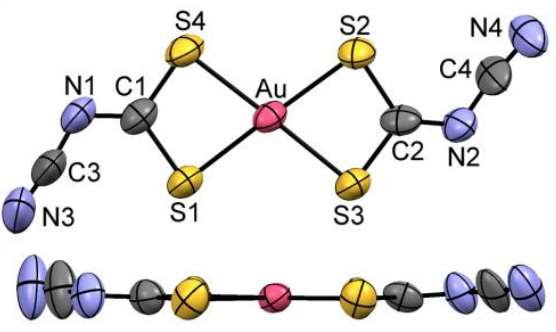

(b)
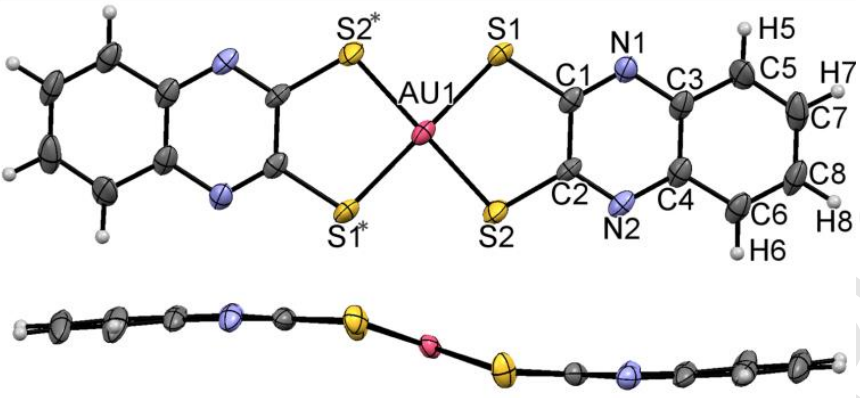

(c)
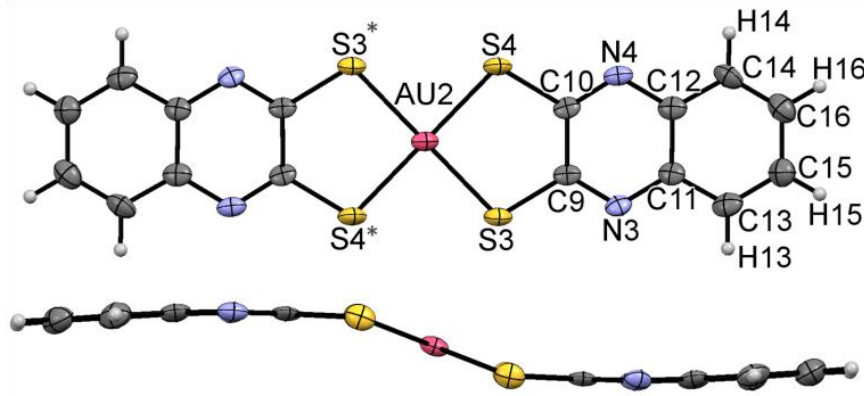
Figure 3

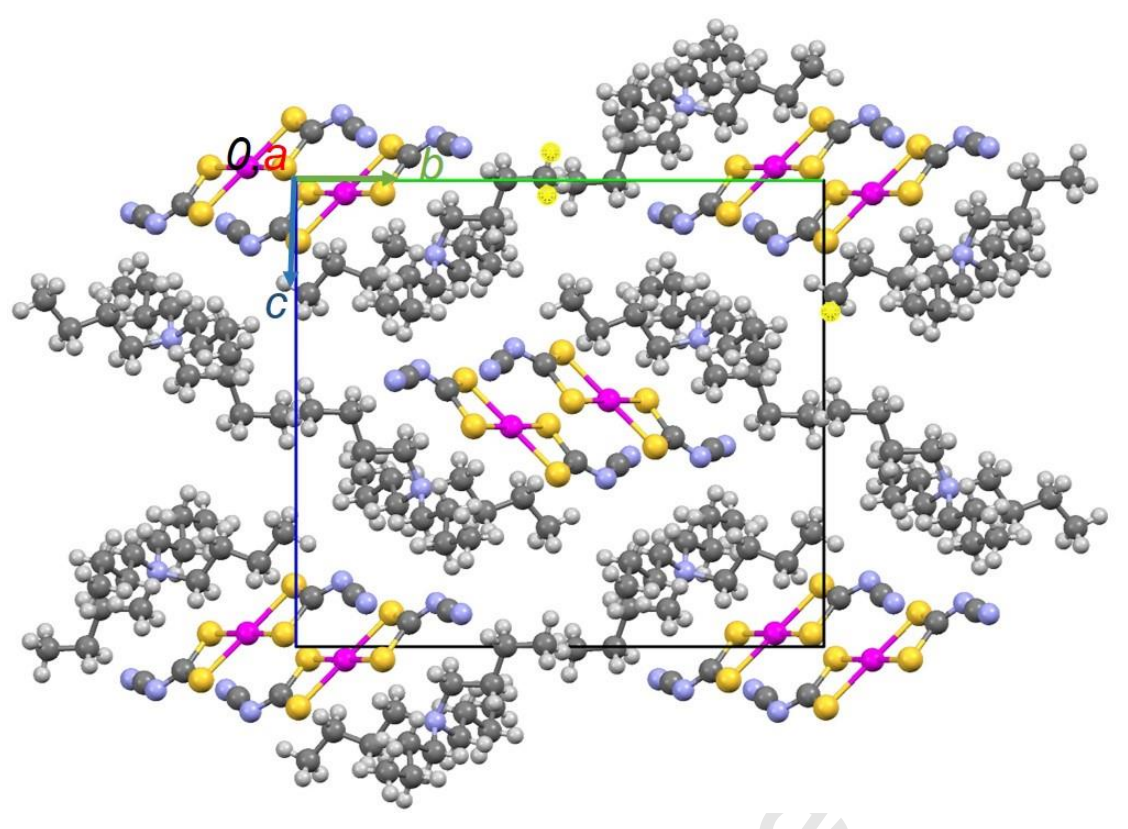


Figure 4

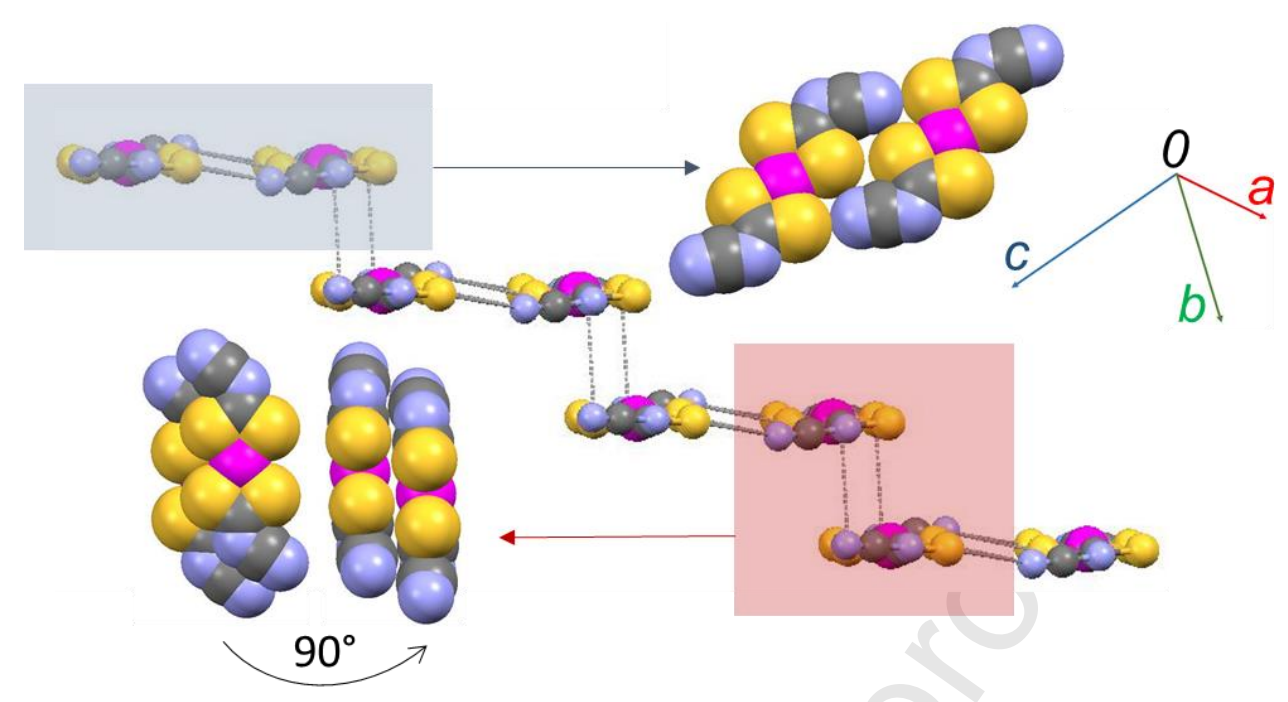


Figure 5

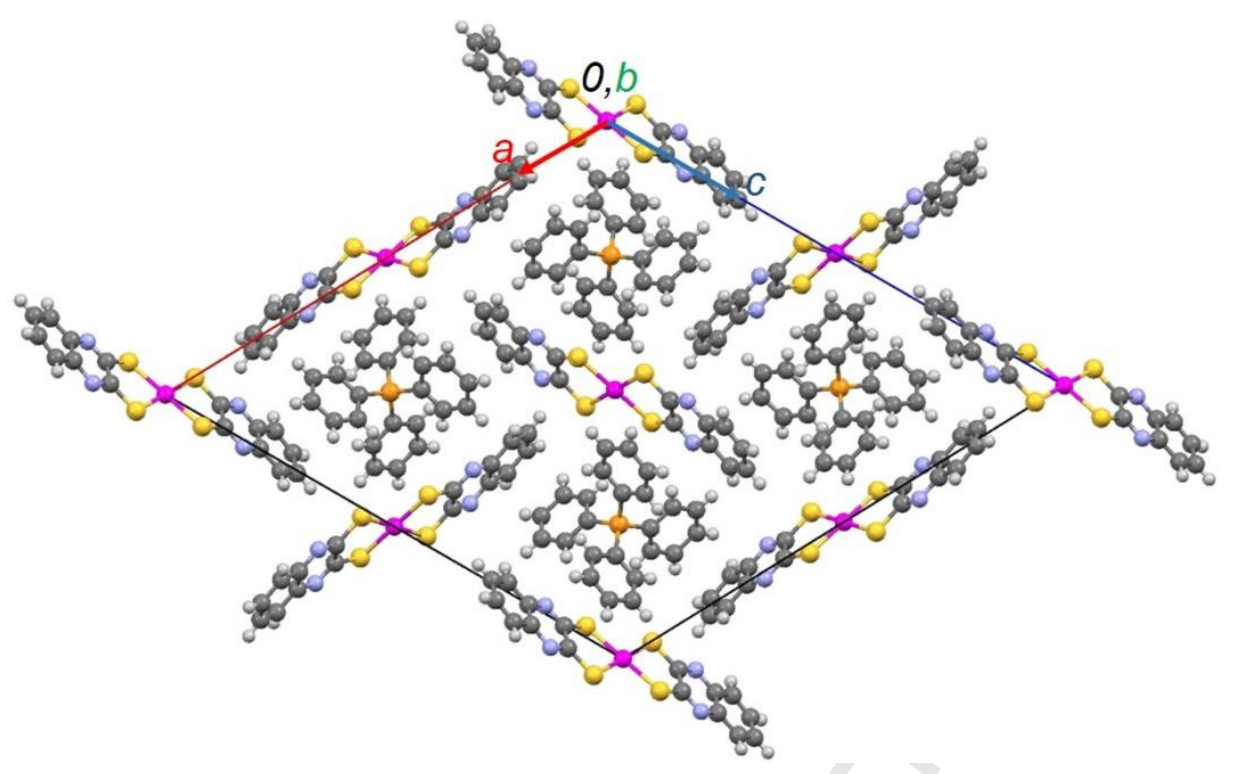


Figure 6
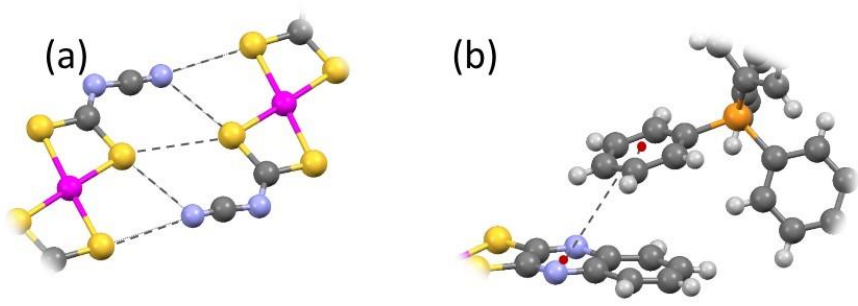

(c)

(d) gege

(e)
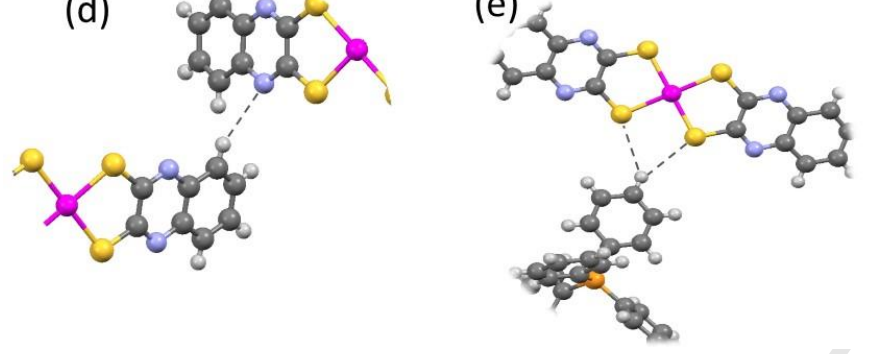

(f)
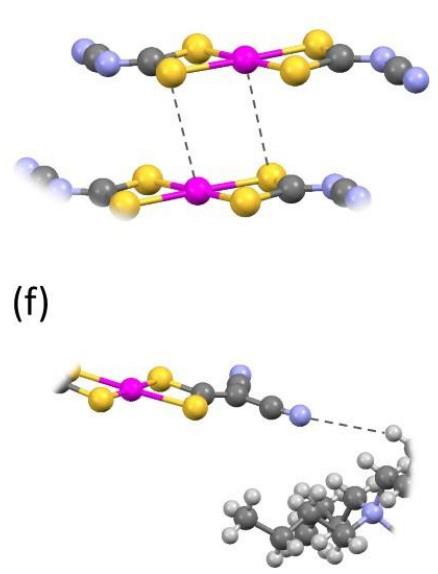


\section{Figure 7}

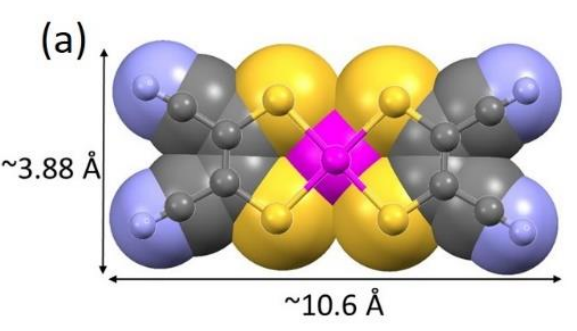

(c)

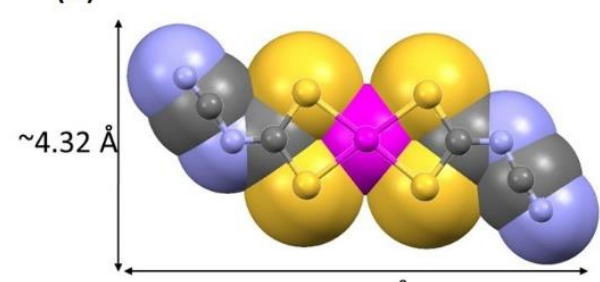

$\sim 10.7 \AA$

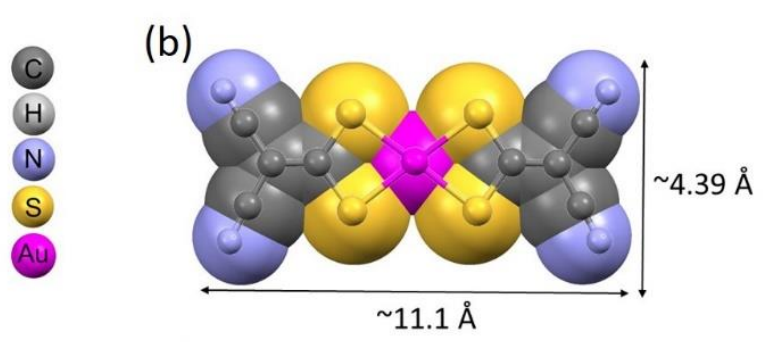

(d)

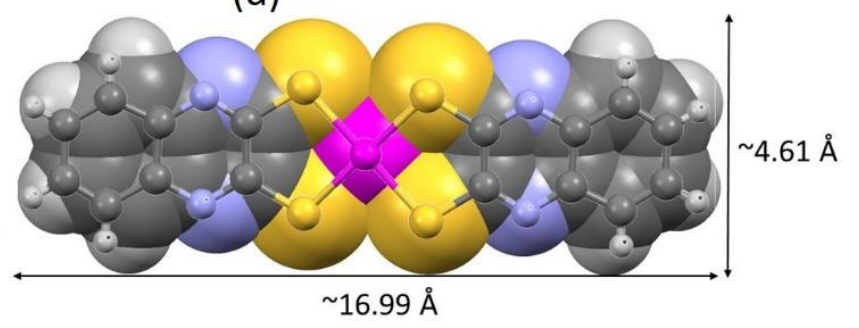


Figure 8

(a)

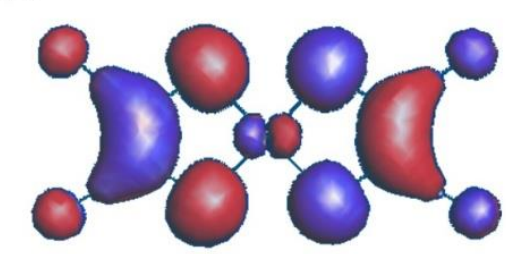

(c)

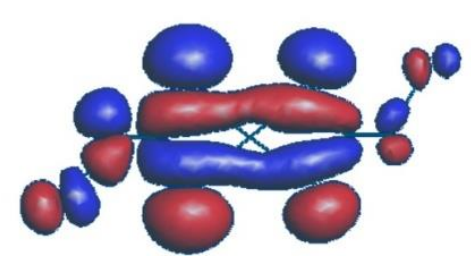

(b)

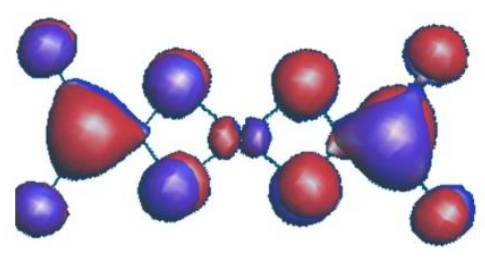

(d)

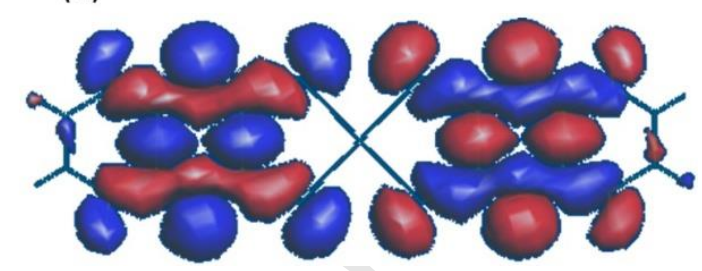


Figure 9

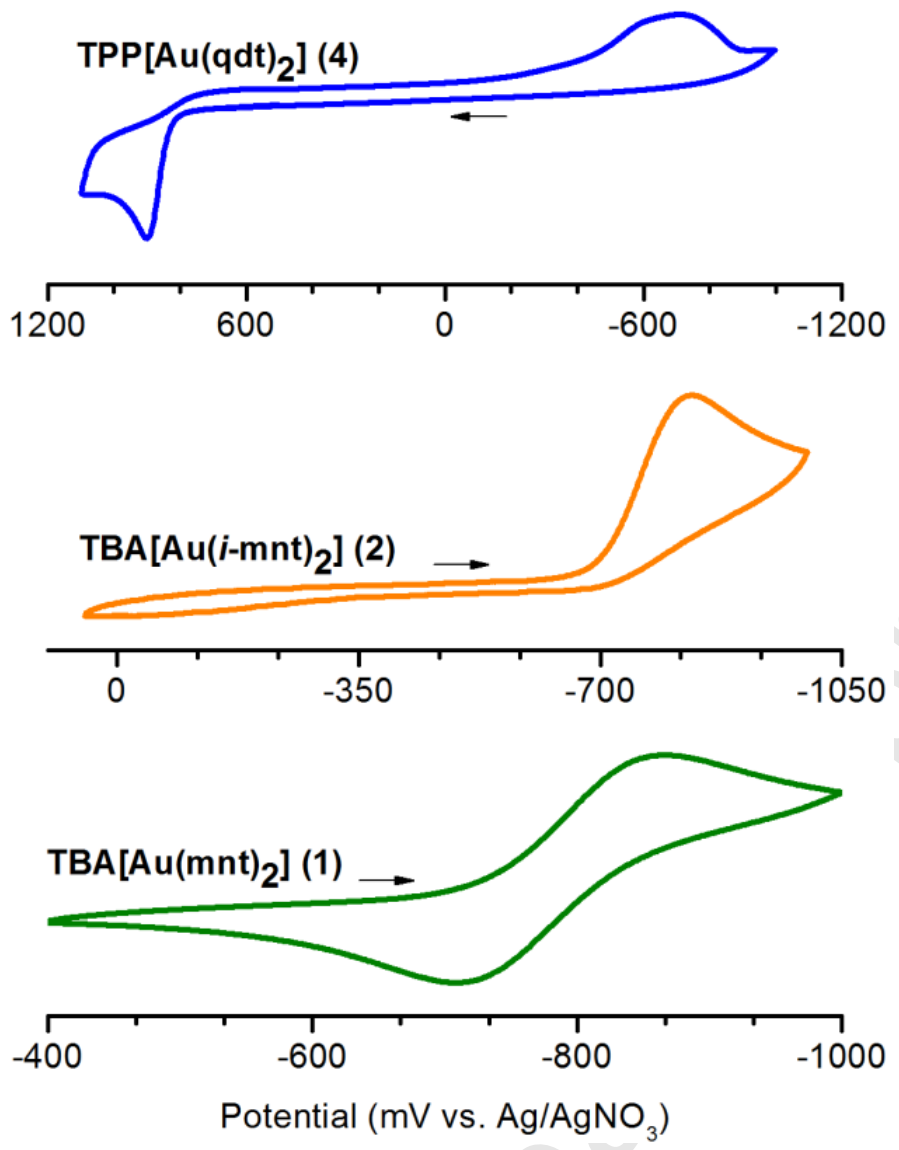


Figure 10

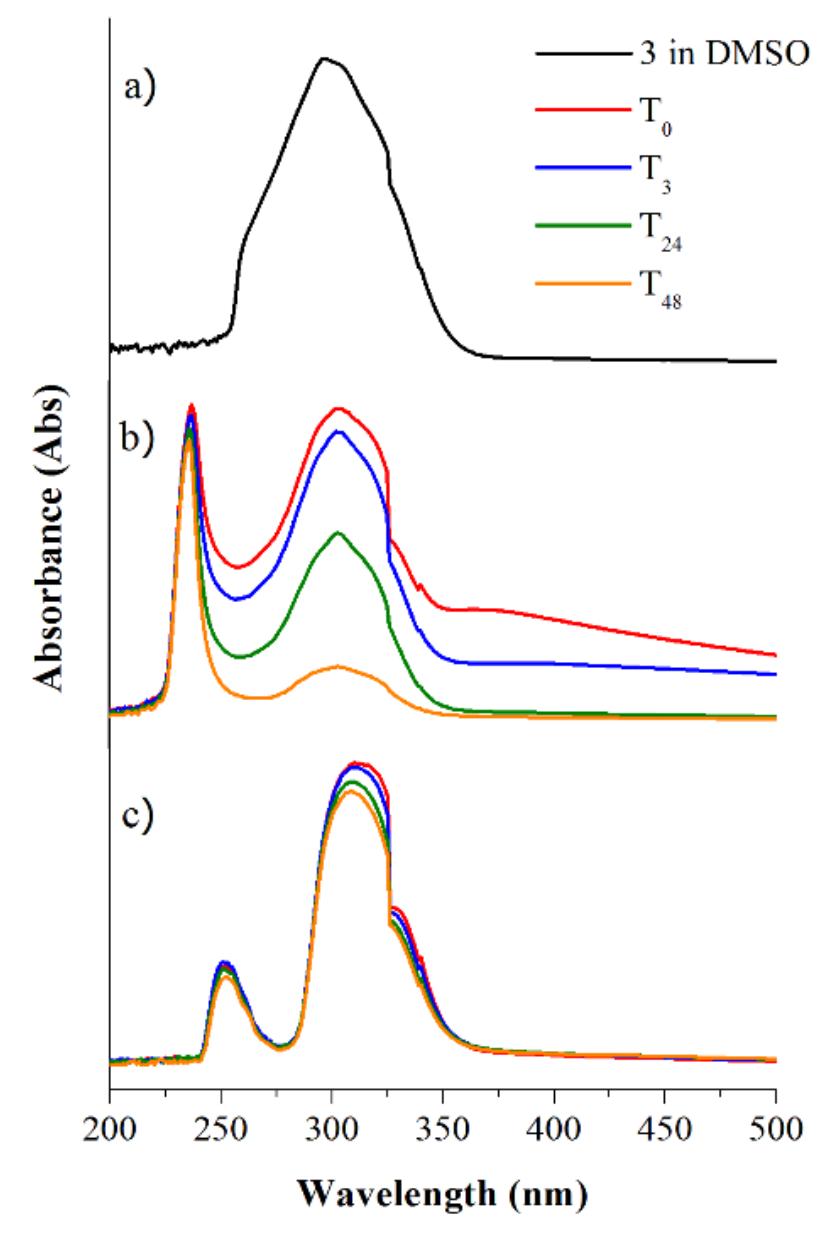


Figure 11

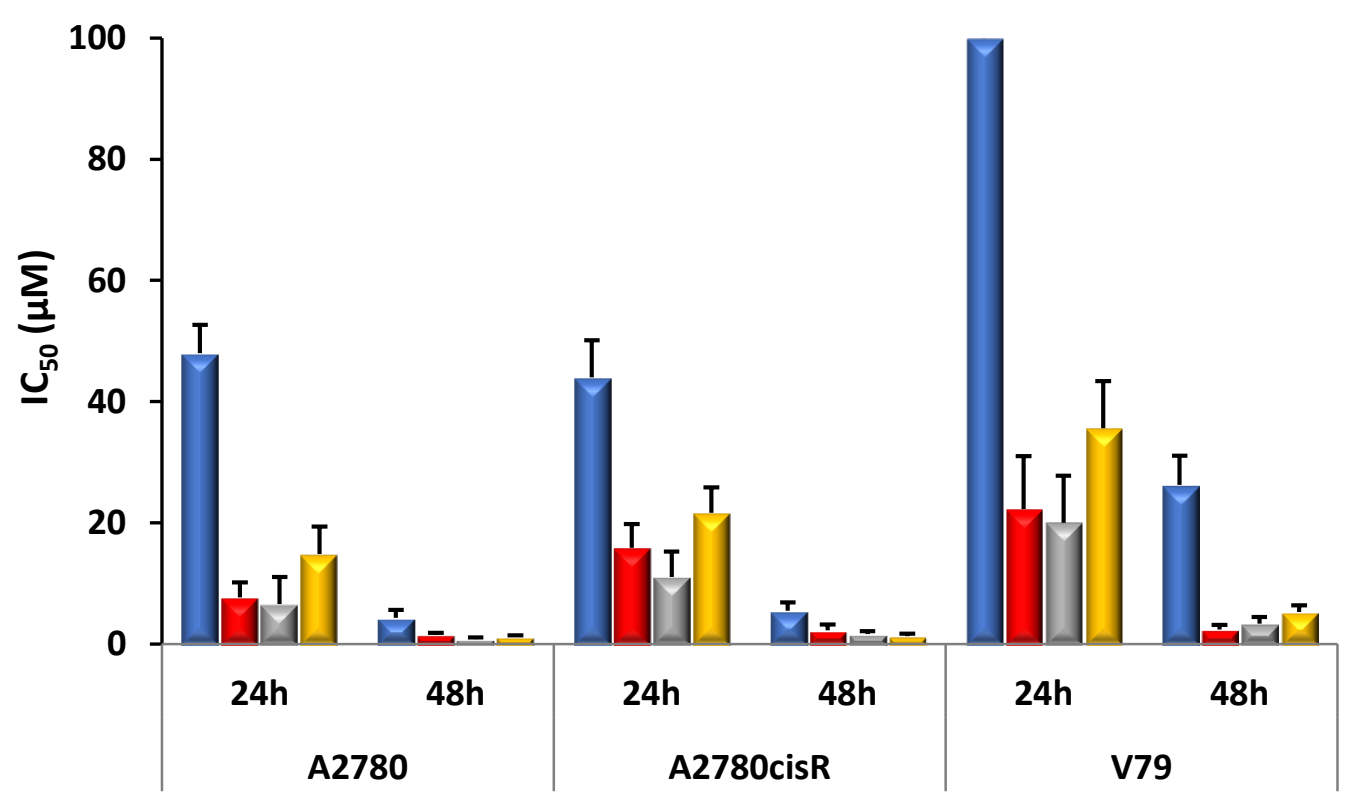

回1回2回34 
Figure 12

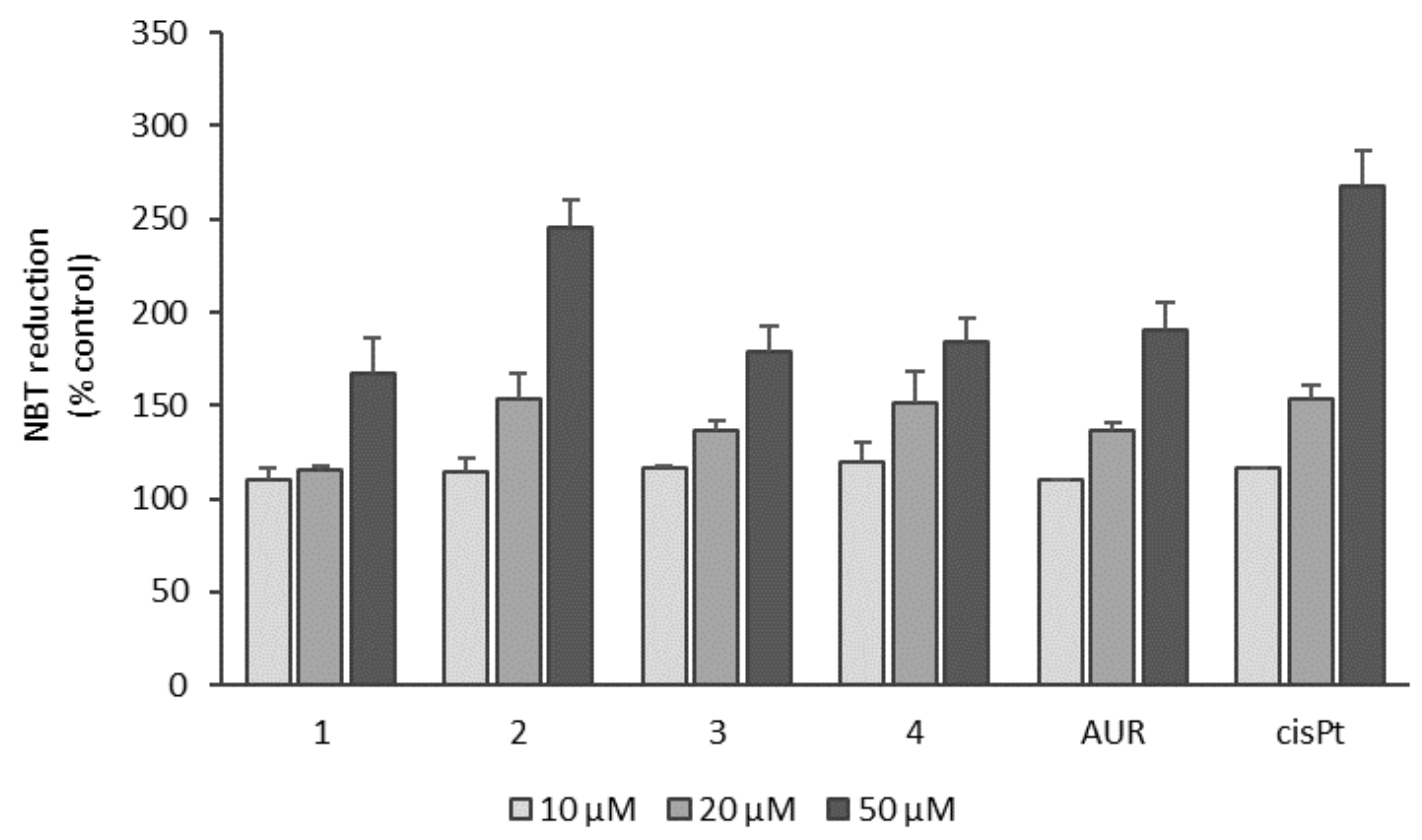


Figure 13

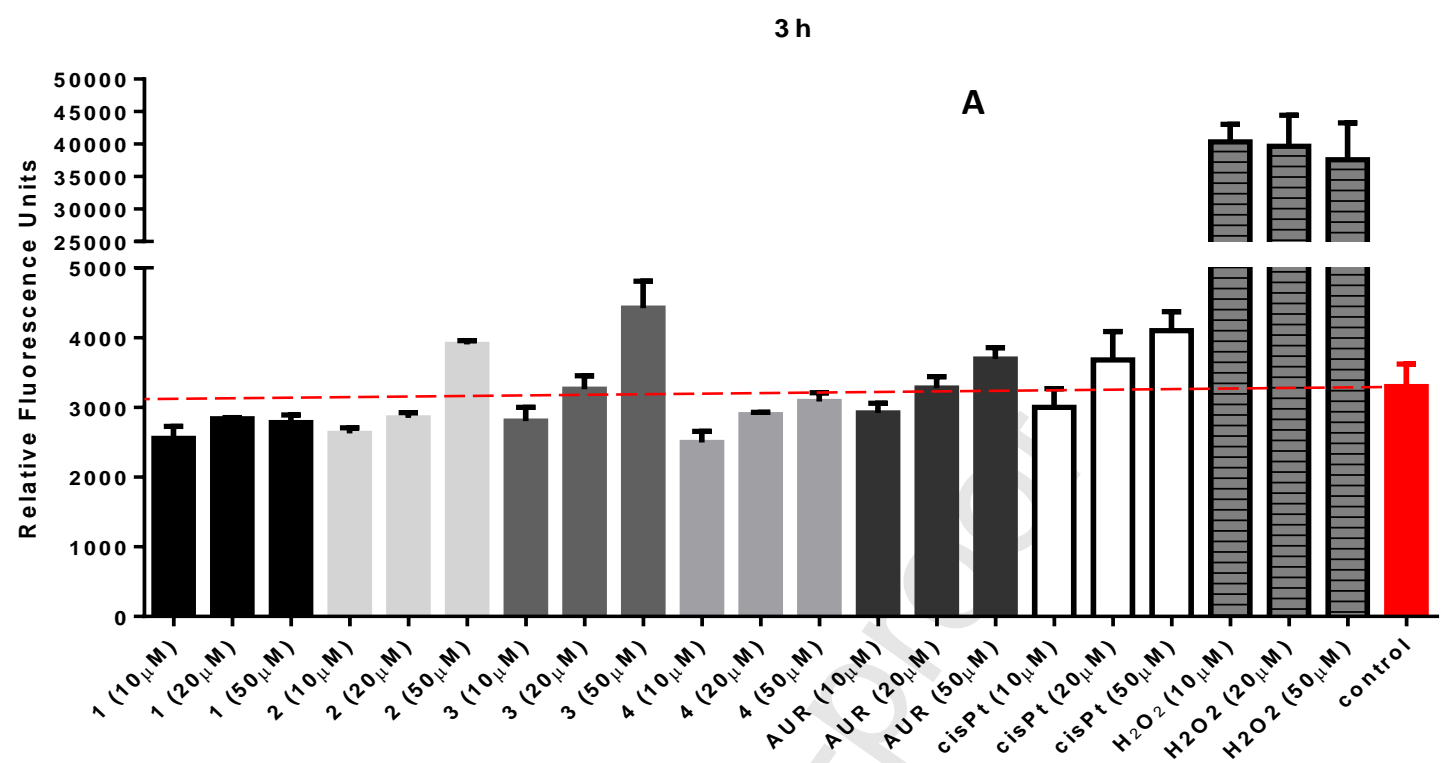

$3 h$

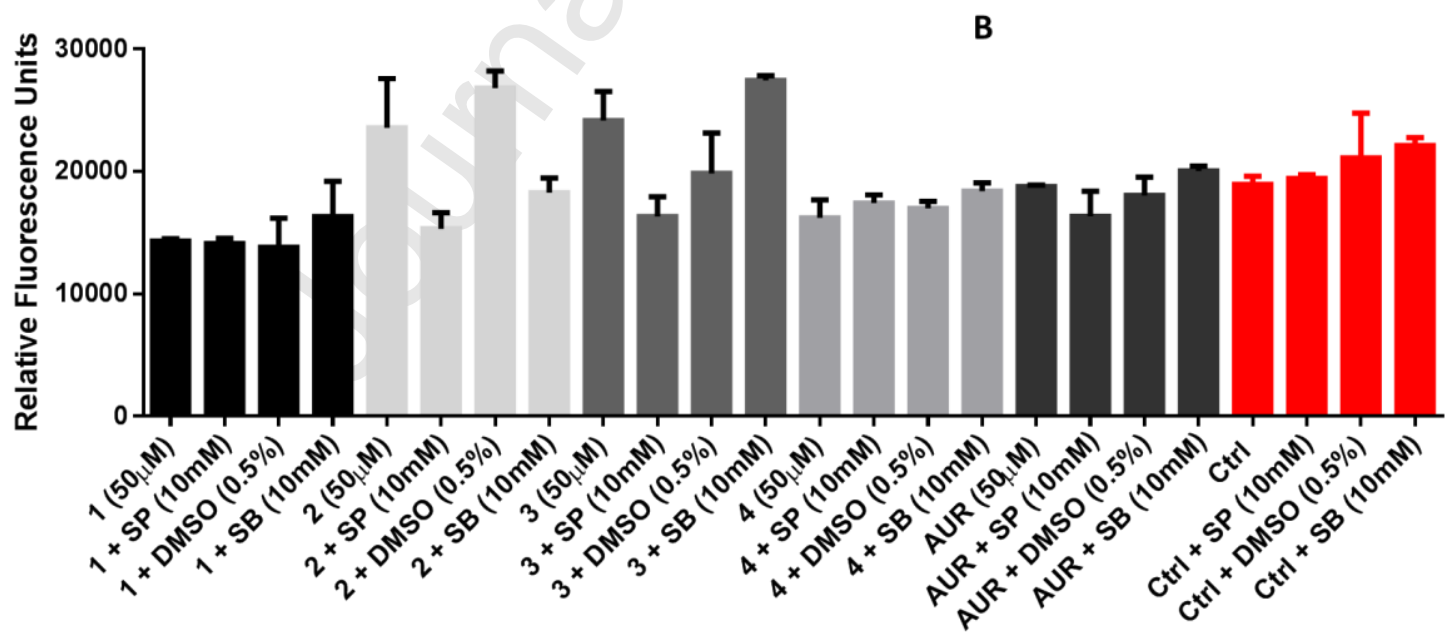


Figure 14

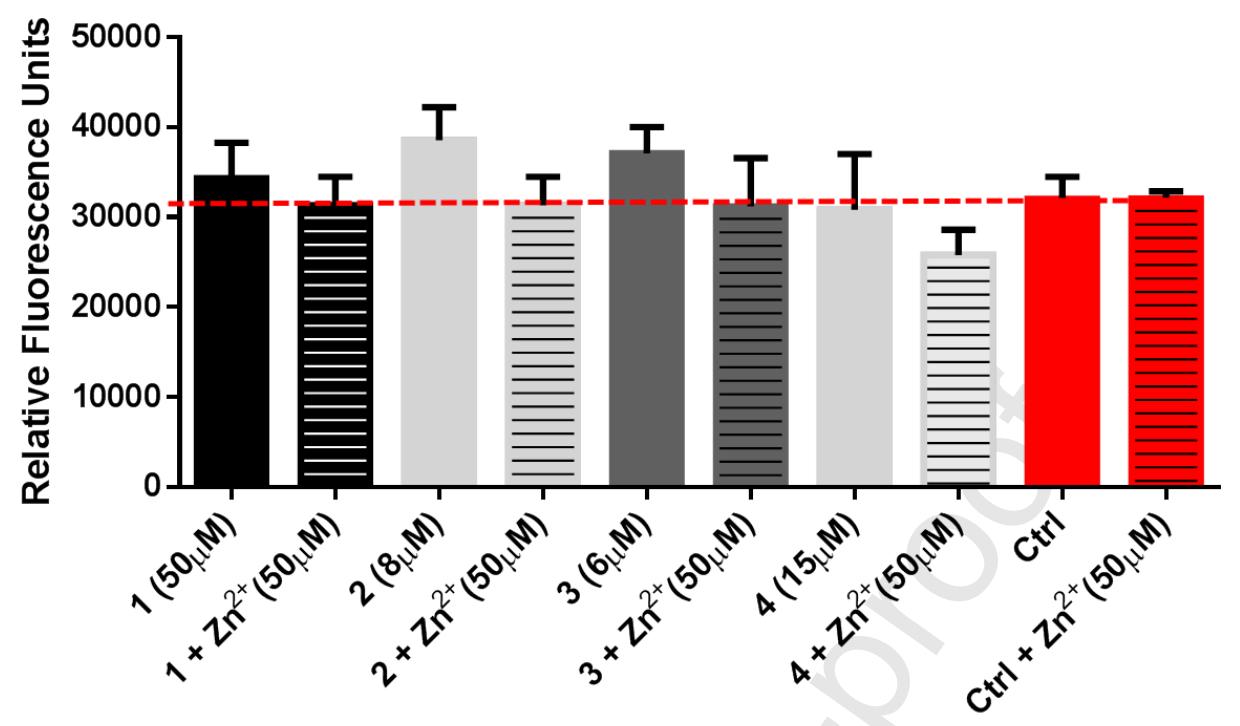




\section{Figure 15}
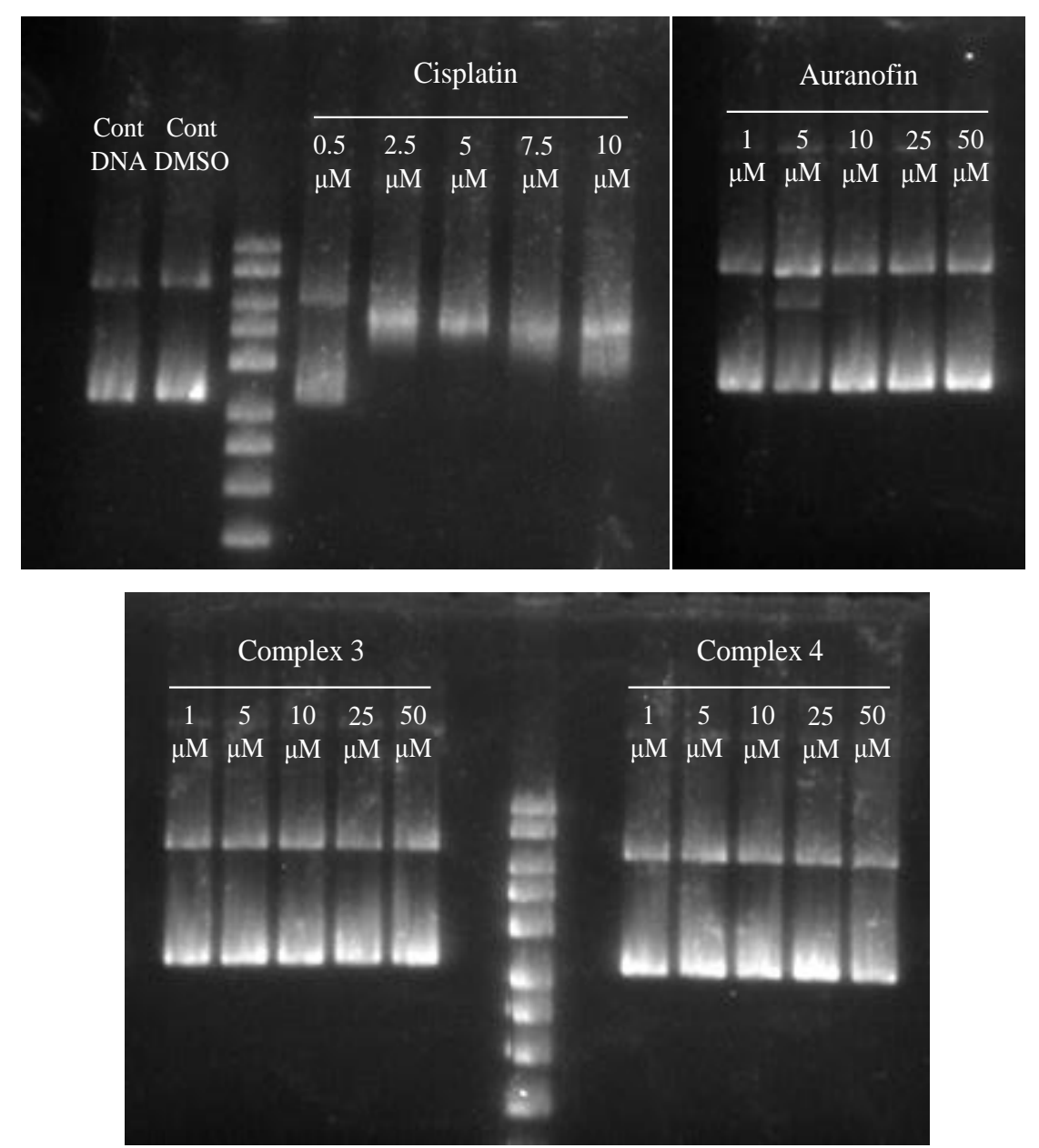


\section{Graphical abstract}

Highlights

- Four homeleptic monoanionic gold bisdithiolate complexes were characterized.

- Complexes redox properties were characterized by cyclic voltammetry.

- The complexes were tested for their antimicrobial and antitumor activities.

- The most redox stable complex showed higher antimicrobial and antitumoral activities.

- The mechanism of action may involve the induction of ROS, mainly superoxide. 